\title{
The World of Contract and the World of Gift
}

\author{
Melvin Aron Eisenberg $\dagger$
}

Under the donative-promise principle, a simple, unrelied-upon donative promise is unenforceable. In the past, this principle has been explained largely on the ground that a rule under which such promises were enforceable would involve significant process problems. In this Article, Professor Eisenberg develops two substantive bases for the donative-promise principle: (1) The world of gift would be impoverished if simple donative promises that are based on affective considerations, such as love or friendship, were folded into the hard-headed world of contract. (2) Where a donative promise is based on affective considerations, in the absence of reliance a donative promisee is morally obliged to release a repenting promisor. In the course of the Article, Professor Eisenberg shows why the principles that govern donative promises play a key role in both contract doctrine and the social significance of contract doctrine. For example, developments in the area of donative promises have been instrumental in leading to a new principle of contract remedies, under which the extent to which a promise is enforceable depends on the reason why the promise is enforceable. Professor Eisenberg also considers the major theses that have been put forward in recent commentary on donative promises, including claims that under present law all seriously made promises are enforceable by expectation damages.

\section{INTRODUCTION}

An important general principle of contract law is that a donative promise - a promise to make a gift-is not legally enforceable simply

Copyright (C) 1997 California Law Review, Inc.

$\dagger$ Professor of Law, University of California, Berkeley. A.B. Columbia, LL.B. Harvard. An earlier version of this article was presented as the Judge Simon E. Sobeloff Lecture at the University of Maryland at Baltimore in 1994. I received valuable comments on that occassion, and valuable comments on later drafts from members of my annual Seminar on Contract Theory. I am also indebted to Richard Hyland and Adam Hirsch, both of whom made a number of penetrating observations on my most recent draft, and to Stuart Mackey, my research assistant, who wrote several exceptionally helpfuI memoranda. 
because it is a promise, although certain kinds of donative promises are enforceable under special principles, like reliance. I will call a donative promise that does not fall within one of these special principles a simple donative promise, and I will call the general principle that a simple donative promise is unenforceable the donative-promise principle. This principle applies no matter how well-evidenced the promise is and no matter how serious the promisor was. Three well-known cases, Dougherty v. Salt, ${ }^{1}$ Fischer v. Union Trust Co., ${ }^{2}$ and Schnell v. Nell, ${ }^{3}$ illustrate this point.

In Dougherty, Tillie signed a blank promissory note under which she promised to pay $\$ 3,000$, at her death or before, to her eight-year-old nephew Charley "for "value received." Charley with the words, "You have always done for me, and I have signed this note for you. Now, do not lose it. Some day it will be valuable." Tillie died with the note still unpaid, and Charley brought suit against her estate. The New York Court of Appeals, in an opinion by Judge Cardozo, held that although Tillie's promise was in writing and recited that value had been received, it was "the voluntary and unenforceable promise of an executory gift."

In Fischer, a father gave his daughter, as a Christmas present, a deed to certain property and also agreed to pay two mortgages on the property totaling $\$ 8,000{ }^{7}$ The daughter then handed a dollar to her father. The father died without paying off one of the mortgages. The mortgage was foreclosed for nonpayment, and the daughter sued her father's estate for breach of the promise to pay the mortgage. The Michigan court held that the transfer of the property was a completed and therefore effective gift, but the promise to pay the mortgages was donative and therefore unenforceable despite the written form of the promise and the symbolic delivery of the dollar. ${ }^{8}$

1. 125 N.E. 94 (N.Y. 1919).

2. 101 N.W. 852 (Mich. 1904).

3. 17 Ind. 29 (1861).

4. 125 N.E. at 95 .

5. Id.

6. Id.

7. See 101 N.W. 852,853 (Mich. 1904).

8. On this issue, the court said:

To say that the one dollar was the real, or such valuable consideration as would of itself sustain a deed of land worth several thousand dollars, is not in accord with reason or common sense.... The real and only consideration for the deed and the agreement, therein contained, to pay the mortgages, was the grantor's love and affection for his unfortunate daughter, and his parental desire to provide for her support after he was dead.... This promise has no additional force because it is contained in the deed. It has no other or greater force than would a promise by him ... to pay her $\$ 8,000$ in money, or his promise to her evideneed by a promissory note for a like amount, and given for the same purpose and the same consideration.

Id. 
In Schnell, Schnell's wife devised $\$ 200$ each to three legatees, but died without assets. ${ }^{9}$ Schnell promised to pay the legatees the amounts that his wife had devised and signed a formal contract which recited that his promise was given "in consideration of one cent" paid by the promisees. ${ }^{10}$ The Indiana court held that Schnell's promise was unenforceable even though it was in writing and cast in the form of a bargain: "The consideration of one cent is, plainly, in this case, merely nominal," that is, bargained for in name only, not in reality, and the promise "was simply one to make a gift."

In the past, the major reason given for the donative-promise principle has been that significant process problems would result if simple donative promises were enforceable-for example, it would be very easy falsely to convince a jury that such a promise had been made-and that the substantive reasons for enforcing simple donative promises were too weak to outweigh those process problems..$^{12}$ In this Article, I will show that there are also two strong substantive reasons for the donativepromise principle: first, that the world of gift would be impoverished if simple donative promises were placed into the world of contract, and second, that in the absence of special circumstances, like reliance, where a donative promise is based on affective considerations, normally the promisee is morally obliged to release a repenting promisor.

I begin by defining the terms that I will use, starting with the term world of contract. The law often defines contract to mean any legally enforceable promise. ${ }^{13}$ The social meaning of contract, however, carries the more restricted connotation of a commercial agreement. I will use the term world of contract in the narrower social sense.

The term world of gift also presents a definitional problem, although of a different sort. I will use gift to mean a voluntary transfer that is made, or at least purports to be made, for affective reasons like love, affection, friendship, comradeship, or gratitude, or to satisfy moral duties or aspirations like benevolence or generosity, and which is not expressly conditioned on a reciprocal exchange. ${ }^{14} \mathrm{I}$ will use the term

9. See 17 Ind. 29,30 (1861).

10. Id.

11. Id. at 32. See also, Haase v. Cardoza, 331 P.2d 419 (Cal. App. 1958) (holding promise unenforceable even though it was based on past consideration and promisor had begun to make payments under the promise); Allen v. Allen, 133 A.2d 116 (D.C. 1957) (stating that nominal consideration does not suffice to make a donative promise enforceable); $D \_$D. C _ $v . T$ W_, 480 S.W.2d 474 (Tex. App. 1972) (finding child support agreement unenforceable in the absence of any separate legal obligation); Dementas v. Estate of Tallas, 764 P.2d 628 (Utah Ct. App. 1988) (holding unenforceable a donative promise in writing and notarized by promisor with his own notarial seal).

12. See infra Part II.A-B.

13. See, e.g., Restatement (Second) of Contracts \& I (198I).

14. Following common usage, the definition of gift used in the text treats as a gift a transfer that has the look and fcel of a gift, in that it purports to be made for affective reasons or to satisfy duties 
world of gift to include both gifts and promises to make gifts. This departs somewhat from legal usage, because the common law draws exceptionally sharp distinctions between gifts and promises to make gifts: Gifts are irrevocable; promises to make gifts are unenforceable. Gifts are part of property law; promises to make gifts are part of contract law. I will use the term world of gift in a more inclusive way, to include both gifts and promises to make gifts, not because there are no meaningful distinctions between the two, but because the manner in which the law should treat promises to make gifts is intimately related to the nature of gifts themselves.

I next consider the term donative promise. It is useful to distinguish this term from the closely related term gratuitous promise. The latter term is sometimes used to include not only donative promises, but all nonreciprocal promises-even promises that lie in the hard-headed world of contract, like promises to hold an offer open for a fixed period

or aspirations, even if the transferor is subjectively motivated by other considerations-short, at least, of a Trojan Horse intention to harm the transferee. So, for example, a voluntary transfer of a painting to a museum that purports to be based on the moral aspiration of public-minded generosity and is not expressly conditioned on a reciprocal exchange is a gift even though the transferor is subjectively motivated by a desire to be invited onto the museum's board or to enhance her status in the community. Similarly, a voluntary transfer of silverware to a couple by a relative, on the occasion of the couple's wedding, that purports to be based on affection, is a gift even though the transferor is subjectively motivated by a desire to avoid censure by other relatives for failure to give a gift when it is customary to do so. The treatment of transfers as gifts because they have the look and feel of gifts is not radically different from the treatment of bargains. A reciprocal transfer that has the look and feel of a bargain-that is, an exchange in which each party purports and appears to view his performance as the price of the other's-is treated by the law as a bargain even if one party was subjectively motivated by a factor other than price. This is the import of Holmes's famous hypothetical that if a painter agrees to paint a portrait for $\$ 500$, the transaction will be treated as a bargain even if the painter is chiefly motivated by a desire for fame. See Oliver Wendell Holmes, The Common LAW 320 (1881).

More particularly, the definition in the text does not restrict gifts to transfers made for purely altruistic motives. Altruism has become a contested concept. In common usage, a transfer is considered altruistic if it is motivated in significant part by an intention to benefit persons other than the transferor (normally, of course, the transferee). Economists, however, have sometimes adopted a more rigorous approach under which a transfer is altruistic only if the transferor gains no utility from the transfer. See, e.g., James Andreoni, Impure Altruism and Donations to Public Goods: A Theory of Warm-Glow Giving, 100 EcoN. J. 464, 464 (1990); James Andreoni, Privately Provided Public Goods in a Large Economy: The Limits of Altruism, 35 J. PuB. EcoN. 57, 57 (1988). Under that definition, a gift would not be altruistic if, for example, the welfare of the donor and the donee are interdependent, so that increasing the donee's welfare increases the donor's welfare, or if the donor derives moral or like satisfaction-a "warm glow"-from the act of giving. In common usage, in contrast, both kinds of gifts would be considered altruistic.

Some legal analyses of gifts take the position that gifts are never or almost nevcr altruistic, because gifts must be reciprocated. See, e.g., Carol M. Rose, Giving, Trading, Thieving and Trusting: How and Why Gifts Become Exchanges and (More Importantly) Vice Versa, 44 FLA. L. REv, 295 (1992) [hereinafter Rose, Giving, Trading, Thieving and Trusting]. For a discussion of this issue, see infra text accompanying notes $5 \mathrm{I}-63$. Although it is certainly important to bear in mind that a gift may be made wholly or (more typically) partly for reasons that benefit the donor, a transfer is not disqualifled from being a gift for that reason. Economists do not claim otherwise: their claim concems what constitutes altruism, not what constitutes gifting. 
of time or nonreciprocal promises to modify a contract. Following this usage, I will use gratuitous promise inclusively to mean all nonreciprocal or apparently nonreciprocal promises, and donative promise more restrictively to mean promises in the world of gift.

Another point of terminology concerns legal discourse. The rules of the common law are based on two kinds of propositions: doctrinal and social. By doctrinal propositions, I mean propositions that purport to state legal rules and that are found in or easily derived from textual sources generally accepted as valid sources of doctrine, such as statutes, precedents, and legal commentaries. By social propositions, I mean all propositions concerning the world other than doctrinal propositions-in particular, propositions of morality, policy, and experience. In the short run, a given doctrinal proposition may be justified by reference to other doctrinal propositions. In the long run, however, only social propositions can justify legal mles; that is, in the long run, a legal rule can only be justified on the ground that, after giving appropriate weight to all applicable social propositions and making appropriate choices or accommodations where social propositions conflict, the rule is, on balance, better than competing mles. ${ }^{\text {is }}$

The structure of this Article is as follows: I begin in Part I by briefly sketching three waves of American scholarship on donative promises. Part $I I$ then considers the doctrinal significance of donative promises and the social significance of donative-promise doctrine. Part III concerns the world of gift, and more particularly the nature of gifts and the differences between gift and bargain in our society. Part IV builds on Part III by developing moral reasons, relating to the nature of the world of gift, why simple donative promises should be unenforceable, and also shows why these reasons are consistent with the mles under which special kinds of donative promises, like those that have been relied upon, are enforceable. Finally, Part $\mathrm{V}$ examines the position taken in some recent commentary that simple donative promises are enforceable under current law if seriously made.

I

Three Waves of Donative-Promise Scholarship

From the mid-nineteenth century through the first part of the twentieth century, a school of thought, now referred to as classical contract law, held sway over contract theory. Classical contract law theorists made the mistake of thinking that legal rules could be justified simply on doctrinal grounds. Classical theory began with certain doctrinal propositions that were regarded as axiomatic in the sense that they were

15. See Melvin Aron Eisenberg, the Nature of the Common Law (1988). 
self-evident. It then purported to derive other doctrinal propositions by logical deduction from those axioms and to justify those other propositions on the ground that they had been derived by deduction. ${ }^{16}$ As Holmes said, disparagingly, "I sometimes tell students that the law schools pursue an inspirational combined with a logical method, that is, the postulates are taken for granted upon authority without inquiry into their worth, and then logic is used as the only tool to develop the results." $" 17$

One of the axioms of classical contract law was the bargain theory of consideration. Under this axiom, only bargain promises "had consideration"- that is, were enforceable-as a matter of principle, although it was recognized that certain other kinds of promises, like promises under seal, might be enforceable on largely historical grounds. One corollary of the bargain theory was that donative promises, which under the axiom did not have consideration, were not enforceable.

\section{A. The First Wave}

Because of the axiomatic structure of classical contract law, that school presented no systematic social justification for the donativepromise principle, although fragmentary justifications could be found in various authorities. ${ }^{18}$ Not until the period 1936-1942 did systematic justifications of the principle emerge in commentaries. The most important of these commentaries was Lon Fuller's great article, Consideration and Form. ${ }^{19}$

Fuller posited three possible substantive bases and two possible "formal" bases-bases rooted in form-for enforcing promises. The

16. See, e.g., C.C. Langdell, Summary of the Law of Contracts 15, 20-21 (2d ed. 1880 ).

The acceptance....must be communicated to the original offerer, and until such communication the contract is not made.... Upon this ... point, however, there has been much difference of opinion, and it has been supposed to be pretty well settled in England and this country that the contract is complete the moment the letter of acceptance is mailed.... It has been claimed that the purposes of substantial justice, and the interests of contracting parties as understood by themselves, will be best served by holding that the contract is complete the moment the letter of acceptance is mailed; and cases have been put to show that the contrary view would produce not only unjust but absurd results. The true Id. answer to this argument is, that it is irrelevant....

17. Oliver Wendell Holmes, law in Science and Science in Law, in Collected Legal PAPERS 210, 238 (1920).

18. See, e.g., Davis \& Co. v. Morgan, 43 S.E. 732,733 (Ga. 1903) (enforcing donative promises might bring such obligations "into compctition with the absolute duties to wife and children,.... and make the law an instrument by which a man could be forced to be generous before he was just"); Richard's Executor v. Richards, $46 \mathrm{~Pa}$. 78, 82 (1863) ("It would be exceedingly hurtful to the freedom of social intercourse to create even a suspicion in the public mind, that those kind offers of advice and assistance, which take place among friends and kindred, could be converted into contracts which the law would enforce.").

19. Lon L. Fuller, Consideration and Form, 41 CoLUM. L. REv. 799 (1941). 
substantive bases were the protection of reliance, the prevention of unjust enrichment, and the effectuation of private autonomy. The formal bases were the provision of evidentiary safeguards that ensured a promise had actually been made and cautionary safeguards that prevented inconsiderate action by the promisor.

Fuller concluded that none of the substantive bases of enforceability support the enforcement of simple donative promises. Such promises involve neither reliance nor unjust enrichment and "do not present an especially pressing case"20 for the application of the principle of effectuating regulation by private autonomy. The force of that principle weakens as it is extended beyond exchange. Unlike a promise of exchange, "which conduces to the production of wealth and the division of labor," a gift, he said, is a "sterile transaction." "'21 The formal bases, Fuller concluded, not only failed to support the enforcement of simple donative promises, but argued against such enforcement: donative promises are exceptionally easy to fabricate, and their characteristics normally fail to provide assurances against inconsiderate action. Several other articles during this period came to comparable conclusions. ${ }^{22}$

\section{B. The Second Wave}

After the early 1940s, there was only scattered commentary on the donative-promise principle ${ }^{23}$ until the period 1977-1980, when a second wave of donative-promise scholarship emerged, including articles by Posner, Goetz and Scott, and myself. ${ }^{24}$ Like the articles in the first wave of commentary, these articles supported the donative-promise principle, although sometimes on different bases.

20. Id. at 815 .

21. Id. (quoting C. Bufnolr, Proprieté et Contrat 487 (1900)).

22. See, e.g., Ashbel G. Gulliver \& Catherine J. Tilson, Classification of Gratuitous Transfers, 51 YALE L.J. 1, 4 (1941); Harold C. Havighurst, Consideration, Ethics and Administration, 42 Colum. L. REv. 1, 12 (1942); Hays, Formal Contracts and Consideration: A Legislative Program, 41 Colum. L. REv. 849, 852-53 (1941); Willis, Rationale of the Law of Contracts, 11 Ind. L.J. 227, 230 (1936).

23. See e.g., John P. Dawson, GiFts AND Promises (1980) (comparing Continental and American law).

24. Between the first and second waves, important work was done concerning principles that would make certain kinds of donative promises enforceable. See, e.g., Benjamin F. Boyer, Promissory Estoppel: Principle from Precedents: I, 50 Mich. L. REv. 639 (1952) [hereinafter Boyer, Principle from Precedents $\Pi$ ] (deriving from precedent a reliance justification for the doctrine of promissory estoppel); Benjamin F. Boyer, Promissory Estoppel: Principle from Precedents: $I I, 50$ Mich. L. Rev. 873 (1952) [hereinafter Boyer, Principle from Precedents II] (same); Benjamin F. Boyer, Promissory Estoppel: Requirements and Limitations of the Doctrine, 98 U. PA. L. REv. 459, 462 (1950) (examining the elements of promissory estoppel to determine its requirements and limitations); Stanley D. Henderson, Promises Grounded in the Past: The Idea of Unjust Enrichment and the Law of Contracts, 57 VA. L. REv. 1115 (1971) (discussing unjust enrichment as support for enforcing non-bargain promises). 
In my own article, Donative Promises, ${ }^{25} \mathrm{I}$ argued that the donativepromise principle was justified on grounds similar to those invoked by Fuller. Like Fuller, I analyzed simple donative promises in terms of both substance and process (what Fuller called form). These elements are interrelated. The stronger the substantive interest in enforcing a given kind of promise, the more the law can tolerate process concerns. I argued that the donative-promise principle is justified not on the ground that there is no substantive reason to enforce simple donative promises, but on the ground that the positive substantive reasons in favor of enforcement are outweighed by the negative process reasons against enforcement.

Certainly there are substantive reasons for enforcing simple donative promises. For example, a failure to keep a donative promise causes an injury to the promisee in the form of a disappointed expectation, and donative promises as a class probably tend to move assets from persons with more wealth to persons with less. However, the expectation of a donative promisee is likely to be weak, and although gifting may be an important form of economic activity, the economic effects that would follow from making donative promises enforceable are indeterminate. Although it is possible that more gifts would be made if donative promises were enforceable, it is also possible that making donative promises enforceable would result in less gifting: Many promisors make gifts only because they have earlier promised to do so, and many prospective donative promisors might refrain from promising in the first place if the promise was legally enforceable.

On balance, I concluded, the process problems that enforcement of simple donative promises would entail outweighed the substantive reasons for the enforcement of such promises. As Fuller stressed, simple donative promises raise serious problems of proof: because of the nature of such promises, a claim by $A$ that $B$ made such a promise may be found credible by a jury despite the absence of corroborating evidence. Donative promises also raise serious problems of deliberativeness, because characteristically a donative promisor is emotionally involved with the promisee and therefore may tend to look mainly to the promisee's interests rather than his own.

Furthermore, if the law were to make simple donative promises legally enforceable just on the ground that they are morally binding, then the law should also allow recognized moral excuses as defenses against the enforcement of such promises. Among these excuses are later ingratitude by the promisee and a material adverse change in the promisor's economic station. Although excuses like these can be administered

25. Melvin Aron Eisenberg, Donative Promises, 47 U. CHI. L Rev. 1 (1979). 
by a legal system-they are, for example, recognized in the civil law ${ }^{26}$ they are inherently messy and do not present the sort of issue that our judicial system is good at resolving. More generally, I would now add, any particular donative promise is likely to be subject to a host of extremely fluid implied moral excuses, such as "I find I need the money I promised you for my new business," or "for a retirement home," or "for my sick nephew," and on and on. It is doubtful whether the formal legal system could deal adequately with the fluid nature of these excuses, because the equilibria of affective relationships are too subtle to be regulated by legal rules.

Posner's article, Gratuitous Promises in Economics and Law, ${ }^{27}$ added a new substantive reason for enforcing donative promises. Posner argued that the present value of a donative promise to the promisee must take account of the probability that the promise will not be performed. Accordingly, an enforceable donative promise will have greater utility to the promisee than an unenforceable donative promise. Moreover, since the utilities of a donative promisor and a donative promisee are usually interdependent, if the donative promise has greater utility to the promisee, the promisor herself will derive greater utility from the promise. Even putting aside the time value of money, therefore, under a nonenforceability regime a donative promisor who wants to confer a present value equal to $\$ 100$ must promise to give more than $\$ 100$, while under an enforceability regime, the promisor need only promise to give $\$ 100 .{ }^{28}$

However, Posner pointed out, the enforcement of donative promises would also have process costs: at one level, the cost of litigation, at another, the cost of legal error, that is, the cost of judicial determinations that a donative promise had been made when in fact it had not. ${ }^{29}$ In the case of simple donative promises, the costs of legal error are particularly high because of the difficulty of distinguishing, in casual social relations, between a statement of present intention and a promise. Moreover, because donative promises typically arise in a familial context, the promisee will often have social sanctions at his disposal which may be as or more effective than legal sanctions. Therefore, Posner concluded,

26. See id. at 13-15.

27. Richard A. Posner, Gratuitous Promises in Economics and Law, 6 J. Legal Stud. 411 (1977).

28. Actually, as a practical matter this argument is probably inapplicable in many or most cases, because it depends on the promisor's forming a belief that the promisee thinks there is a significant likelihood that the promise will not be kept. A donative promisee may well so think, but a donative promisor is unlikely to believe that the promisee so thinks, and often or usually the promisor would consider the promisee ungrateful for even entertaining such a thought.

29. Posner, supra note 27, at 411-15. 
weighing the substantive benefits against the process costs, the general principle that simple donative promises are unenforceable is sound.

Goetz and Scott, in their article Enforcing Promises: An Examination of the Basis of Contract,$^{30}$ also began by pointing out a substantive advantage of enforcing donative promises. A promise of any kind allows the promisee to engage in beneficial reliance, that is, actions that would make the promise, if and when kept, more valuable. For example, if Uncle promises to put Niece through college, Niece can increase the value of Uncle's promise by taking courses in high school that will prepare her for college, rather than taking vocational courses that would prepare her to work as soon as she graduates high school, which she would otherwise do. The more certam it is that a promise will be kept, the more beneficial reliance the promisee can prudently engage in and the more valuable the promise will be. ${ }^{31}$

Against this, Goetz and Scott developed a substantive reason for not enforcing simple donative promises. In making a promise, a promisor forgoes opportunities he would have had if he had not made the promise. Often, these lost opportunities will cause the promisor to regret having made the promise. To avoid such regrets, a promisor can take the precaution of making his promise subject to explicit conditions, including conditions relating to his own future state of mind, whose occurrence would cause regret to the promisee if not included in the promise. For example, instead of saying, "I will give you this rug within two years," the promisor might say, "I will give you this rug within two years unless I decide before then to move to a larger house."

In a donative context, a full specification of such conditions would often lead to very heavily conditioned promises. Under a nonenforcement regime, a full specification of such conditions is unnecessary. If, however, simple donative promises were enforceable, then unless donative promisors explicitly and heavily conditioned their promises, they might often be required to perform under circuinstances that would lead them to regret having made the promise. Because the social context in which promisors make donative promises might inhibit the making of heavily conditioned promises, if simple donative promises were

30. Charles J. Goetz \& Robert E. Scott, Enforcing Promises: An Examination of the Basis of Contract, 89 YALE L.J. 1261 (1980).

31. On the other hand, Gordon Fauth, a student in my Seminar on the Theory of Contracts, points out that a donative promisor might prefer promisee-uncertainty. By promising a $\$ 5,000$ gift, the promisor may secure the attention of the promisee to her wishes over the life of the promise, something that an outright gift might not accomphish. Gordon M. Fauth, Jr., Discussion Questions for Seminar in Contracts Theory (Sept. 10, 1996) (unpublished paper, on file with author). 
enforceable, many potential donative promisors would probably prefer making no promise at all to making a heavily conditioned promise. ${ }^{32}$

Accordingly, the legal enforcement of donative promises might produce an excessive reduction in the number of donative promises. In contrast, under a nonenforcement regime, donative promisees can adapt to the risk of nonperformance by limiting their beneficial reliance. Therefore, Goetz and Scott concluded, the net social value of making donative promises enforceable would be less than the net social value of a nonenforcement regime. ${ }^{33}$

\section{The Third Wave}

Recently, a third wave of commentary on simple donative promises has appeared. This wave is distinguished by several features. For one thing, unlike the commentary in the first two waves, much or most of the commentary in the third wave argues that simple donative promises should be enforceable. In addition, although the commentary in the first two waves was almost entirely concerned with social propositions, some of the commentary in the third wave argues that simple donative promises are enforceable as a matter of present legal doctrine. Another feature of the third wave of commentary is its remarkable quantity: at least fourteen articles in this wave have been published since 1988, including an entire symposium issue of a law review. ${ }^{34}$ The balance of this Article will consider this third wave of commentary.

32. To put this differently, although the terms of a bargain promise are normally highly, but not completely, specified, the terms of a donative promise are normally highly unspecified. Making donative promises enforceable might produce a marginal increase in specification, but the increase would be very small, because, given the fluid nature of one's personal life, the kind of specification required would be much more difficult than the kind of specification required for bargain promises. Accordingly, the alternatives for a potential donative promisor would be not to make a promise all, to make a promise with a general kind of specification whose applicability would be very difficult to determine, or to trust the courts to imply specifications on the basis of what the promisor would probably have agreed to if he had engaged in relatively complete specification. The latter two altematives would often seem unwelcome to a prospective promisor, and indeed the last alternative would often secin unwelcome to the courts.

33. Goetz \& Scott's analysis suggests another way to look at Posner's thesis, that because the utilities of a donative promisor and a donative promisee are interdependent, a donor will derive less utility from a promise if it is unenforceable, and therefore will need to promise more than he would like to give, if he is to accomplish his desired effect. Suppose that A wants to make a donative promise to give B $\$ 100$. Under Posner's thesis, if A is operating under an unenforceability regime, he needs to promise B more than $\$ 100$ to confer on B $\$ 100$ worth of utility after discounting for the likelihood of performance. Now suppose that $A$ is operating under an enforceability regime. $A$ then does not have to promise more than $\$ 100$ to confer on B $\$ 100$ worth of utility. However, A now nay promise less than $\$ 100$ to impound the contingency that he may have to keep the promise although he does not want to do so, because unforeseen circumstances may arise before the $\$ 100$ is to be paid.

34. See, e.g, Jane B. Baron, Do We Believe in Generosity?: Reflections on the Relationship Between Gifts and Exchanges, 44 U. FLA. L. REv. 355 (1992); Mary Louise Fellows, Donative Promises Redux, in Property LAW and Legal Education 27 (Peter Hay \& Michael H. Hoeflich eds., 1988) [hereinafter Fellows, Donative Promises Redux]; Mary Louise Fellows, His to Give; His 


\section{II}

\section{The Significance of Donative-Promise Doctrine}

What accounts for the extraordinary outpouring of commentary on donative promises? After all, from the perspective of both law and the social system, donative promises may seem to comprise an exceptionally small segment of contract law. Certainly such promises are not the stuff of which advance sheets are made. Even casebooks devote only limited space to the subject. Despite appearances, however, the treatment of donative promises is fundamental to both contract doctrineparticularly consideration and remedies-and to the social significance of contract doctrine.

\section{A. The Doctrinal Significance of Donative Promises}

\section{Consideration}

To begin with, the treatment of donative promises is a central issue in the doctrine of consideration. This was especially true in classical contract law, where the basic fault line in consideration ran at the boundary between bargain promises and gratuitous promises. Under the bargain theory of consideration, every promise that was not a bargain promise was viewed as a gratuitous promise. "Gratuitous" was therefore virtually synonymous with "unenforceable."

The enforceability of donative promises also plays an essential role in consideration doctrine under modern contract theory. Under modern contract law, there is a marked trend to make all commercial promises enforceable, even if they are not bargain promises. ${ }^{35}$ Partly this is because many commercial promises that do not appear to be bargains

to Receive; Hers to Trust: A Response to Carol M. Rose, 44 U. FLA. L. REv. 329 (1992); E. Allen Farnsworth, Promises to Make Gifts, 43 AM. J. CoMp. L. 359 (1995); Robert H. Frank, The Differences Between Gifts and Exchange: Comment on Carol Rose, 44 U. FLA. L. Rev. 319 (1992); James Gordley, Enforcing Promises, 82 CALif. L. REv. 547 (1995); Emily Fowler Hartigan, Rose and Apple-Original Gifts?, 44 U. FLA. L. REv. 347 (1992); Andrew Kull, Reconsidering Gratuitous Promises, 21 J. Legal Stud. 39 (1992); Rose, supra note 14; Rose, Giving Some Back-A Reprise, 44 U. Fla. L. Rev. 365 (1992); Steven Shavell, An Economic Analysis of Altruism and Deferred Gifis, 20 J. Legal Stud. 401 (1991); Steve Thel \& Edward Yorio, The Promissory Busis of Past Consideration, 78 VA. L. REv. 1045 (1992); Wessman, Retraining the Gatekeeper: Further Reflections on the Doctrine of Consdieration, 29 Loyola L. Rev. 713, 817-44 (1996); Edward Yorio \& Steve Thel, The Promissory Basis of Section 90, 101 YALE L.J. 111 (1991); see also, Michael J. TREBILCOCK, THE Limits OF FrEEDOM OF CONTRACT 177-87 (1993); Samuel Stoljar, Enforcing Benevolent Promises, 12 SYdney L. Rev. 17 (1989).

35. See, e.g., Daniel A. Farber \& John H. Matheson, Beyond Promissory Estoppel: Contract Lav and the "Invisible Handshake," 52 CHI. L. REv. 903 (1985) (identifying an emerging trend toward enforcing "any promise made in futherance of an economic activity"); James D. Gordon III, A Dialogue About the Doctrine of Consideration, 75 CoRnell L. REv. 987 (1990) (exploring the fit of the doctrine of consideration and the commercial-gift dichotomy with the purposes of contraet law); James D. Gordon III, Consideration and the Commercial-Gift Dichotumy, 44 VAND. L. REv. 283 (1991) (arguing that the commercial-gift dichotomy better deseribes the line between enforceable and unenforceable promises than does the doctrine of consideration). 
turn out to have a bargain element when properly analyzed. For example, a promise to hold an offer open for a fixed amount of time may seem to be nonreciprocal. However, an offeror normally makes such a promise to induce the offeree to invest more time and money in investigating the offer than she would if the promise were not made. Therefore, such a promise is normally part of a bargain in which a promise to hold an offer open is exchanged for greater deliberation by the offeree, and the consequent increased chance of acceptance. Even commercial promises that lack a bargain element normally are in aid of or facilitate bargains, and enforceability can be justified on that ground.

As contract law moves toward enforcing all commercial promises, even those that appear gratuitous, the major issue raised by the doctrine of consideration becomes whether and to what extent gratuitous noncommercial promises-donative promises-should be enforced. Accordingly, just as in classical contract law the basic fault line in consideration ran at the boundary between bargain promises and gratuitous promises, so in modern contract law the basic fault line in consideration runs at the boundary between commercial promises and donative promises.

\section{Remedies}

Donative promises have also played a critical role in the development of modern principles of contract damages. Classical contract law employed a pure expectation-damages regime: Another axiom of classical contract law was that the breach of any enforceable promise gives rise to a right to expectation damages. This axiom was closely related to the bargain theory of consideration. Under that theory, only bargain promises are enforceable. Because expectation damages are indeed appropriate for bargain promises, it became natural to identify expectation damages as the axiomatic remedy for breach of an enforceable promise. Under modern principles of consideration, however, certain kinds of donative promises, such as those that have been relied upon, are now enforceable. ${ }^{36}$ This development has played a critical role in damages doctrine by leading to a more nuanced damages regime, which admits different damages measures for different kinds of enforceable promises.

Take, for example, cases in which a promisee relied on a donative promise. Reliance does not completely satisfy the formal or process concerns that underlie the donative promise principle. Reliance may provide some evidence that a promise was actually made, but it seldom provides full assurance because the kind of reliance that is involved in a donative context-like making a purchase or taking a trip-is often consistent with either the existence or the nonexistence of a promise.

36. See infra text accompanying notes $42-44$. 
Similarly, the prospect of reliance may have a cautionary effect on a donative promisor, but since the promisor's motive is often altruistic rather than calculating, even a relied-upon promise may have been made without deliberation.

Substantively, however, reliance has a decisive impact, because it makes a qualitative change in the nature of the promisee's injury. A relying promisee has suffered not merely disappointment of the expectation created by the promise, but an actual diminution of his wealth. A donative promisor who leads a promisee to engage in reasonable reliance that diminishes the promisee's wealth, without reimbursing that diminution, wrongfully inflicts a significant injury for which the promisee should be compensated. The strong substantive interest of the promisee in such cases outweighs the process concerns.

So strong was the bargain theory under classical contract law that in principle a donative promise was deemed unenforceable even if it had been relied upon.$^{37}$ Restatement (First) of Contracts properly broke with classical contract law on this issue and, in its famous section 90 , recognized that a relied-upon promise should be enforceable:

A promise which the promisor should reasonably expect to induce action or forbearance of a definite and substantial character on the part of the promisee and which does induce such action or forbearance is binding if injustice can be avoided only by enforcement of the promise. ${ }^{38}$

There remained the issue of remedy, which section 90 did not directly address. In one of the most famous passages in contract law, Williston insisted, in the debate on the A.L.I. floor, that if a promise was enforceable under section 90 , it was enforceable to its full extent-that is, by expectation damages. ${ }^{39}$ When pressed for justification of this apparently extraordinary result, Williston fell back on the extreme conceptualism of which he was occasionally capable:

Either the promise is binding or it is not. If the promise is binding it has to be enforced as it is made.... I could leave this whole thing to the subject of quasi contracts so that the promisee under those circumstances shall never recover on the promise

37. See, e.g., Kirksey v. Kirksey, 8 Ala. 131 (1845). The brother-in-law of Antillico, a widow, wrote to her that if she left her residence and moved to his farm, he would give her a place on the farm where she could raise her family. Antillico gave up her residence and moved to the farm, but after several years the brother-in-law evicted her. The court held that the promise was unenforceable as a "mere gratuity." Id. See also Brawn v. Lyford, 69 A. 544 (Me. 1907); Thorne v. Deas, 4 Johns. 84 (N.Y. 1809). But see Steele v. Steele, 23 A. 959 (Md. 1892) (holding that detrimental reliance may constitute 'sufficient consideration to support a contract'); Devecmon v. Shaw, 14 A. 464 (Md. 1888) (same); Ricketts v. Scothorn, 77 N.W. 365 (Neb. 1898) (reliance by promisee estopped promisor from denying that consideration was given). See also text at notes 86-88.

38. Restatement (First) of Contracts $\S 90$ (1932).

39. See 4 A.L.I. Proc. 88-89, 91-92, 95-96, 98-99, app. rule 3.5 (1926). 
but he shall recover such an amount as will fairly compensate him for any injury incurred; but it seems to me you have to take one leg or the other. You have either to say the promise is binding or you have to go on the theory of restoring the status quo. ${ }^{40}$

The position Williston took in this passage reflects the axiom of classical contract law, that a person injured by the breach of an enforceable promise has a right to expectation damages. However, damages for breach of a bargain promise are not measured by expectation for axiomatic reasons, but because that measure is related to the underlying reasons for enforcing bargain promises. Although the rhetoric of contract law treats expectation damages as compensatory, that characterization is misleading, if not erroneous. As Fuller trenchantly observed, expectation damages "compensate' the plaintiff by giving him something he never had. This seems on the face of things a queer sort of "compensation." "41

Rather than being compensatory, expectation damages are awarded for breach of bargain promises because they implement the reasons why the law enforces bargain promises. A market economy depends heavily on two overlapping types of bargain: credit transactions-that is, exchanges over time in which Party 1 is required to perform before Party 2 is required to pay for the performance-and wholly executory contracts, in which no performance is rendered at the time the contract is made. In an exchange over time in which Party 2 breaches, expectation damages are simply the equivalent of the price that Party 2 agreed to pay for a bargained-for performance that she has already accepted. Any measure less than expectation damages would therefore render exchanges over time insecure for the party who is to perform first. Wholly executory contracts for future delivery are typically entered into to enable the parties to make reliable plans by which complex inputs can be integrated, to allocate the risk of price changes, or both. Efficiency normally requires that such planning and allocation should be given effect, and the award of expectation damages conduces to that end. Furthermore, the price term of a bargain, which is the basis of expectation damages, is normally the most efficient price of the commodity that is the subject of the bargain, because permitting the interaction of buyers and sellers to determine the price of a commodity will normally move the commodity to its highest-valued uses and best allocate the factors necessary for the commodity's production.

40. Id. at 103-04; see also id. at 94; 5 SAMuel Williston, A Treatise ON THE LAWS OF Contracts $\$ 1338$, at 3764 n.7 (rev. ed. Samuel Williston \& George J. Thompson eds., 1937).

41. L. L. Fuller \& William R. Perdue, Jr., The Reliance Interest in Contract Damages: I, 46 YALE LJ. 52, 53 (1936). 
Finally, the extent to which actors will be ready to engage in exchanges over time, and are able to make reliable integrative plans and to allocate the risk of price changes through executory contracts, depends heavily on the probability that bargain promises will be kept. The expectation measure gives the parties to a bargain the appropriate incentives to perform rather than breach and to take appropriate precautions to ensure that they will be able to perform. Because the expectation measure places on the breaching party the loss of the other party's share of the contract's joint value, it sweeps that loss into each party's self-interested calculus in a decision whether to perform or to breach. Similarly, the expectation measure causes each party to internalize the cost of failure to take adequate precaution against breach, and therefore creates an incentive for efficient precaution.

Accordingly, bargain promises are enforced by expectation damages not to compensate for the promisee's injury, but because of the social interest in facilitating commerce and the consequent interest in ensuring that bargains will be enforceable according to their terms. Given the reasons for bargain promises, the parties themselves probably would choose the expectation measure if they addressed the issue of damages.

In contrast, expectation damages are not required to ensure that a relying donative promisee is paid the price of a performance she has rendered, or to enable a donative promisee to plan the future integration of complex inputs reliably, or to allocate the risk of price changes. Indeed, simple donative promises should be and are unenforceable. Reliance makes a donative promise enforceable because, and only because, the promisee has injuriously relied upon the promise. The promisee's damages for breach of a relied-upon donative promise should correspond to the reason for enforcement and therefore should be measured by the injurious reliance. Accordingly, under modern remedies doctrine where a donative promise is enforced because of the promisee's reliance, expectation damages are not required, and reliance damages may be awarded instead. Restatement (Second) of Contracts section 90 properly rejects the position that damages for breach of a relied-upon donative promise must be measured by expectation. Rather, it provides, "The remedy granted for breach may be limited as justice requires."42 The express purpose of this sentence is to sanction the use of a reliance measure of damages under section $90 .^{43}$

A similar differentiation of damage measures has occurred in the case of donative promises to render a performance that the promisor

42. Restatement (SECOND) OF CONTRACTS $\$ 90(1)$ (1981).

43. See id. at $\$ 90$ reporter's note; see also 42 A.L.I. PROc. $296-97$ (I965) (remarks of Professor Braucher). 
was morally obliged to render even before the promise was made. Such promises are often said to be based on "past" or "moral" consideration. Of course, every promise gives rise to a moral obligation. The distinctive feature of past-consideration cases is that a separate moral obligation preexists and is the basis of the promise.

A particularly compelling case for the enforceability of such promises arises when the moral obligation is to make compensation for a past benefit that the promisee had conferred upon the promisor. If $A$ has conferred a benefit on B without B's prior request, but under circumstances such that $\mathrm{B}$ is morally obliged to compensate $\mathrm{A}$ for the benefit, there are two major reasons why $B$ should not also be legally obliged to compensate A. First, we want to protect persons, like B, against liability for benefits that have been officiously conferred upon them, which they might have declined to accept and pay for if they had been given the choice. Second, the value of the benefit to B may be very difficult to measure. If, however, in such a case, B subsequently promises to discharge her moral obligation by repaying $A$ for the benefit, both obstacles will normally be removed. Such a promise should therefore be enforceable.

On historical grounds, classical contract law recognized the enforceability of a few special categories of promises based on past consideration, such as promises to pay debts that were barred by the statute of limitations or discharged by bankruptcy. As a matter of principle, however, classical contract law, grounded on the bargain theory of consideration, took the position that a donative promise based on a past benefit was no more enforceable than any other donative promise. But just as Restatement (First) of Contracts section 90 established a new principle under which a relied-upon donative promise is enforceable, so Restatement (Second) of Contracts section 86 established a new principle under which a donative promise to compensate for a past benefit is enforceable.

Similarly, just as expectation damages are often inappropriate for promises that fall within section 90 , so too they are often inappropriate for promises that fall within section 86 . The reason for enforcing such promises is that the promisor was under a preexisting moral obligation to compensate the promisee for a benefit conferred. Because enforcement of the promise is based on the prior benefit, the promisee's recovery should ordinarily be limited to an amount that is related to the benefit. That is essentially the position taken in Restatement (Second) of Contracts section 86 . Section $86(1)$ provides, "A promise made in recognition of a benefit previously received by the promisor from the promisee is binding to the extent necessary to prevent injustice." ${ }^{\prime 4}$

44. Restatement (SECond) of Contracts §86(1) (1981). 
Section $86(2)$ provides, "A promise is not binding under [section $86(1)]$... to the extent that its value is disproportionate to the benefit. ${ }^{, 45}$

In short, once the bargain theory of consideration broke down, so too did the axiom that a person injured by the breach of an enforceable promise had a right to expectation damages. Just as the development of modern principles that make certain classes of donative promises enforceable has been the major factor leading to the breakdown of the bargain theory of consideration, so too the development of those principles has been the major factor leading to the breakdown of the expectation-damages axiom, and the replacement of that axiom with a new, albeit implicit, principle: the extent to which a promise is enforced depends on the reason why the promise is enforced.

\section{B. The Social Significance of Donative-Promise Doctrine}

As shown above, donative promises are central to the formulation of doctrine in the areas of consideration and remedies. Moreover, the doctrinal treatment of donative promises, once formulated, has independent social significance. The principle that bargain promises are legally enforceable, while simple donative promises are not, implicates fundamental questions of social value. Furthermore, because both bargains and gifts involve transfers, the different treatment accorded bargain promises and promises to make gifts drives to the surface the question of what distinguishes gifts from bargains. Finally, the enforceability of donative promises bears directly on one of the deepest social questions of contract law: whether contract law should be based on the deontological objective of ensuring that promisors keep their promises because it is morally right that promises are kept, or on utilitarian considerations of facilitating commerce and compensating injured promisees. I will call the former a promisor-based conception of contract law and the latter a promisee-based conception.

One of the most important works in the third wave of commentary on donative promises, Yorio and Thel's The Promissory Basis of Section 90 , well articulates the difference between these two conceptions of contract law. ${ }^{46}$ Yorio and Thel point out that since the publication of

45. Restatement (SECOND) of Contracts $\$ 86(2)$ (1981). There will be many cases under section 86 where enforcement to the full extent of the promise is appropriate-not because expectation damages are appropriate, but either because the promise approximates the market value of the benefit or because in the absence of a market the value of the benefit is best mensurcd by the promise. (For example, in cases involving a heroic rescue there is no ready market value for the promisee's services.) In such cases, and perhaps others, the value of the benefit may be best mensured by the utility of the benefit to the benefited party, and the promise will be the best evidence of that utility.

46. See Yorio \& Thel, supra note 34. 
Fuller and Perdue's article, The Reliance Interest in Contract

Damages: ${ }^{47}$

[I]t has become conventional to view contract remedies in terms of the promisee's interests in the remedy awarded. Fuller and Perdue's pervasive influence is shown most dramatically by the first section dealing with remedies in the Second Restatement of Contracts. Entitled "Purposes of Remedies," it lays out the three interests of the promisee [expectation, reliance, and restitution] identified in the Fuller and Perdue article, which is prominently cited in the reporter's note following the section. The section presumes that the sole purpose of contract remedies is to protect interests of the promisee. In keeping with this presumption, the Second Restatement added language allowing courts to limit the remedy in Section 90 cases, thereby sanctioning the award of reliance damages. If contract remedies serve to protect interests of the promisee and if the promisee's claim under Section 90 derives from injury to her reliance interest, the remedy awarded ought to be limited to reliance damages.

Contract remedies look entirely different, however, when viewed from the perspective of the promisor. With this shift in focus come very different conclusions regarding the proper remedy for breach. Professor Charles Fried is the most recent expositor of a promisor-based approach to contract remedies. Fried explains much of contract law in terms of the moral obligation of promise. His primary focus is on the promisor, who has an interest in requiring that promises be kept so that others will take her at her word. By enforcing contracts, the legal system supports principles of trust and integrity. From this perspective, Fried concludes that the proper remedy for breach of contract is expectation damages that put the promisee in the same position in which she would have been had the promisor kept her word. ${ }^{48}$

A complete discussion of the promisor- and promisee-based conceptions of contract law would require a separate article. For present purposes, it is fair to say that American contract law, although in some measure influenced by both conceptions, tends to be promisee-based, that is, tends to focus on compensating injured promisees and facilitating commerce rather than on promise-keeping as an end in itself. For example, in determining whether an expression used by an addressor constitutes a promise, the issue is normally not whether the addressor actually intended to make a promise, but whether the addressee actually

47. Fuller \& Perdue, supra note 41.

48. Yorio \& Thel, supra note 34, at 120-21 (footnotes omitted) (discussing Charles Fried, Contract as Promise (1981)). 
and reasonably understood the expression to be a promise. ${ }^{49}$ Similarly, damages in contract law are normally based on considerations of injury and social policy rather than on the promisor's gain from breach. ${ }^{30}$ The donative-promise principle and its exceptions also reflect this utilitarian conception of contract law. Donative promises are unenforceable unless there is a special social reason for enforcement. When there is a special social reason for enforcement, the measure of damages is based on that reason.

In contrast to present contract law, much of the commentary in the third wave of scholarship on donative promises seems to be implicitly or explicitly founded on a deontological, promisor-based conception of contract law. That is one reason why much of this commentary tends to reject both the donative-promise principle and the damages rules that accompany the major exceptions to that principle. The text or subtext is that morality requires the enforcement of simple donative promises. I will show in Part IV, however, that a regime in which simple donative promises were enforceable would actually undermine important social and moral values. As a prelude to that showing, I will first explore the nature of the transfers that are the subject of donative promises.

\section{III \\ THE WORLD OF GIFT}

As developed in Part II, donative promises, although at first glance an inconsequential area of contract law, in fact stand close to its center. The third wave of commentary on donative promises reflects that central position, both indirectly, by the very mass of the commentary, and directly, by its extensive focus on the relevant social and doctrinal issues. One strand of the commentary in this wave argues that donative promises should be enforceable on the basis of social propositions. Another strand argues that the donative-promise principle is not actually the law. Because of the volume of the commentary in the third wave I will not attempt to discuss all of the literature, and instead will focus on a leading exemplar of each of these strands. However, my analysis of arguments in those exemplars applies to much of the remaining work as well.

I will begin with the strand of the literature that argues that donative promises should be enforceable on the basis of social propositions. Because this critique of the donative-promise principle is so fundamental, it drives to the surface some deep elements of the world of gift that remained submerged in the first two waves of commentary. However,

49. See, e.g., Embry v. Hargadine-McKittrick Dry Goods Co., 105 S.W. 777 (Mo. Ct. App. 1907).

50. See, e.g., United States Naval Inst. v. Charter Communications, Inc., 936 F.2d 692 (2d Cir. 1991); Hadley v. Baxendale, 145 Eng. Rep. 145 (Ex. Ch. 1854). 
contrary to the position taken in much of the third-wave commentary, the deep elements of the world of gift provide a better, substantive basis for not enforcing simple donative promises, while at the same time explaining why certain kinds of donative promises should be and are enforceable.

Jane Baron makes one of the most important social critiques of the donative-promise principle in her article, Gifts, Bargains, and Form. ${ }^{51}$ Based partly on the anthropological literature concerning gift-giving, Baron argues that gifts as well as bargains involve exchanges and reciprocity, because a gift must not only be given but accepted, and the acceptance of a gift by a donee often entails the assumption of certain social obligations to the donor.

For non-lawyers, gifts are exchanges. They are not necessarily exchanges of goods, and they are distinct in important ways from the conventional exchanges of the market, but they are exchanges nonetheless.

In a seminal essay written in 1925, the French sociologist/anthropologist Marcel Mauss suggested that in the "primitive" or "archaic" societies that anthropologists had theretofore studied, patterns of giving which seemed voluntary, disinterested and spontaneous were in fact obligatory and interested. In such societies, where groups exchange not only goods but also "courtesies, entertainments, ritual, military assistance, women, children, dances, and feasts," gift-exchanges constitute "total social phenomena, [in which] all kinds of institutions find simultaneous expression: religious, legal, moral, and economic." This system... involves three interdependent obligations-to give, to receive, and to repay .... 52

Since gifts involve exchange and reciprocity, Baron argues, the law cannot distinguish donative promises from bargain promises on the ground that bargain promises involve exchange and reciprocity while donative promises do not. Rather, Baron concludes, the markedly different treatment of donative and bargain promises shows that the law either devalues gifts, reflects a social devaluation of gifts, or both. In short, the real reason for the donative-promise principle is that bargain

51. 64 IND. L.J. 155 (1989). Baron is concerned not only with the enforceability of donative promises, but also with the formalities required for making gifts testamentary dispositions. I will deal only with the aspects of her argument that concern donative promises, perhaps at some injustice to her argument as a whole.

52. Id. at 194-95 (footnotes omitted) (quoting MARCEl Mauss, The GifT: Forms AND Functions of Exchanges in ARChaic Societies) (I. Cunnison trans. 1954). Carol Rose makes a similar point-although on somewhat different grounds and for a somewhat different purpose-in her article, Giving, Trading, Thieving, and Trusting: "Gift [I] eaks into [e]xchange." Rose, supra note 14, at 302 . 
promises are deemed socially important while donative promises are not:

The substantive function of the consideration requirement, in this view, is to mark off acts and promises of sufficient inherent importance to warrant legal intervention, regardless of form, from acts and promises which lack such importance. Executory bargains are said to be in the first category, promises of gifts in the second. The justification of [the doctrine of] consideration in substantive terms thus reflects the view not only that promises of bargains and of gifts are fundamentally different, but also that the former are more important than the latter. . . .

When the accounts of the functions of consideration and [requirements] of form are combined, they send a single message. Gifts are marginal. Socially uncommon, economically unimportant, morally unworthy, gifts can claim little on their own behalf. The weakness of their claim justifies the law in treating them with only the greatest reluctance and suspicion..$^{53}$

Baron's point that gifts often involve an element of exchange or reciprocity is true and important (although Baron somewhat overemphasizes that element by stressing anthropological studies of cultures in which ritual gift exchanges play a crucial social role). However, while gifts often involve an element of exchange or reciprocity, gifts are not bargains. Our culture distinguishes between gifts and bargains not only legally, but socially..$^{54}$

But if both gifts and bargains may involve reciprocity and exchange, what is the difference between gifts and bargains? The answer is that a bargain involves a transfer that is expressly conditioned on a reciprocal exchange, so that each party is entitled by the terms of the bargain to a compensatory reciprocal performance, and in which each performance is presented as the price of the other party's performance. In contrast, a gift is a transfer that is inade, or at least purports to be made, not for economic gain, but for affective reasons or to satisfy moral duties or aspirations, and which is not expressly conditioned on a reciprocal exchange, so that any later exchange that occurs is not, or at least does not purport to be, viewed by the parties as the price of the transfer.

Because gifts are not expressly conditioned on an exchange, gifts may involve exchange or reciprocity but need not. Consider, for

53. Baron, supra note 51, at 180-81, 189 (footnotes omitted).

54. Baron recognizes this. See id. at 195 ("To see gifts as exchanges-and not as the one-sided transactions depicted in legal discussions-is not necessarily to see gifts as 'bargains.'”)

What constitutes a gift, and the consequences of a gift, may be culturally dependent in significant part. The discussion in this Article of the social attributes of gifts is based on the meaning and incidents of gifts in our society. 
example, anonymous gifts, small gifts to charities, gifts to strangers, and services to the dying. More important, even where a gift does involve exchange or reciprocity, the exchange or reciprocity must have, or at least must purport to have, a voluntary element: it must be based, or purport to be based, on affective or moral motives, and it may not be expressly required by the terms of the original transfer or viewed by the parties as the price of the original transfer.

The voluntary element may be small. It may even be close to formal, in the sense that the donee's social freedom not to reciprocate is very limited. Nevertheless, if a reciprocal transfer is made because it is expressly required by the terms of an original transfer, or if it is presented as a price of the original transfer, so that there is not even an appearance of voluntariness, then the original transfer is not a gift. A donor may hope for reciprocity. He may even expect reciprocity. But he cannot demand or require reciprocity without disqualifying his transfer as a gift..$^{55}$

For example, suppose that $A$ gives a beautiful silver ring to $B$, and shortly thereafter $B$ gives a beautiful watch to $A$ or makes love to $A$. If, when A gave B the ring, A said, "I will give you this ring if you agree to give me back a watch in return," or "I will give you this ring if you agree to make love to me tonight," A has made a bargam, not a gift. If, on the other hand, $A$ makes no condition when giving the ring to $B$, and $A$ and $B$ do not see giving the watch or making love as the price of $A$ 's ring, but rather as an act of affection or love, there is a gift.

Moreover, there is a gift in such a case even though in fact B gave the watch to $A$ or made love to $A$ in part to reciprocate for the ring (after all, even lovers reciprocate), even though some reciprocal act was expected by $A$, and even though it is clear that $A$ would believe that a failure to reciprocate in some way for the gift of the ring would be in some way wrong. If the terms of the original transfer do not require $B$ to reciprocate, and the reciprocal act is not viewed by the parties as a price of that transfer, there is a gift. A reciprocal act may be hoped for or even expected in a gift context, but it cannot be required.

This may be turned around by looking at the reciprocal transfer rather than the original transfer. Just as an original transfer is not a gift if it is conditioned on or viewed as the price of a reciprocal transfer, so a reciprocal transfer is not a gift if it is viewed as a payment for the

\section{According to Baron,}

While a non-economic exchange involves "a general expectation of some future return, its exact nature is definitely not stipulated in advance." Moreover, "the nature of the return cannot be bargained about but must be left to the discretion of the one who makes it."

Reciprocation can never be assured or enforced, but instead is a matter of trust or gratitude. Id. at 196 (footnotes omitted) (emphasis in original) (quoting PETER M. BLAU, ExCHANGE AND POWER IN SOCIAL LIFE 93 (1964)). 
original transfer. A reciprocal donative transfer must be presented not as arising out of an explicit obligation to reciprocate, but as arising out of a desire to reciprocate. For example, suppose that after $\mathrm{A}$ gives $\mathrm{B}$ a wedding present worth $\$ 500$, B gives $A \$ 500$ for $A$ 's own wedding and says, "I am giving you $\$ 500$ as a gift to pay you for your wedding present to me." Or suppose that A gives $B$ a friendship ring, and $B$ gives $A$ a ring in return, stating, "I am giving you this ring to pay you for your ring." In both cases, despite B's use of the word "giving," the reciprocal transfer would not be a gift. Indeed, in both cases the reciprocal transfer would be more likely to poison the relationship between $A$ and $B$ than to promote it. ${ }^{56}$

The difference between gifts and bargains is also reflected in a cluster of other attributes. For example, a bargain is about commodities (using that term in its broadest sense to include goods, real estate, and services), and a bargain focuses on the amount of money or the monetary value of the commodity that each party transfers. In contrast, gifts are, or must at least purport to be, about either affective relationships or the expression of moral duties or aspirations. In bargains, commodities are an end in themselves; in gifts, commodities are a means to an end. In bargains, the nexus is the commodity; in gifts of objects, the nexus is the relationship or the embedded moral values. Of course, a gifted object is a commodity, but a gift is not simply the transfer of an object. The significance of a gifted object hes, or must purport to lie, not so much in the monetary value the transferee places on the gift (except insofar as that monetary value may be evidence of how much the donor values the donee) as in the totemic way in which the gift reflects or manifests the relationship with the donee, in the tangible expression of a moral value that is important to the donor, or both.

The totemic aspect of gifted objects is indicated in other ways. For example, a party who has bargained for a commodity is free to-and is often expected to-immediately resell the commodity in the market. In contrast, a donee who immediately sells a gifted object in the market insults the donor by treating the object purely as a commodity rather than as both a commodity and a totem of the relationship.

Indeed, the totemic aspect of gifted objects may lead a prospective donee to decline a gift despite the gifted object's market value. A

56. Miss Manners makes this point nicely:

Dear Miss Manners: I have had many visitors in my home, some of them my children's friends. I have great judgment problems defining who pays what.... Should we accept any money donated at the end of their stay?

Gentle Reader: When you or your children issue invitations to visit, do you mention that you are running a bed and breakfast? ...

Offering cash at the end of the stay is an insult-suggesting that a visit to you is for sale-however much you might appreciate such an insult.

Judith Martin, Miss Manners, If They Visit You, You Pay For Them, S.F. Chron., Oct. 7, 1996, at D8. 
person who is offered a commodity in a bargain transaction will normally accept or reject the offer on the basis of the difference between the monetary value she places on the commodity and the monetary price she is asked to pay. In contrast, a person who is offered a gift may decline to accept it even though the gift has monetary value, and he is not required to provide anything tangible in exchange, because the gift would be an inappropriate totem. For example, if A and B are dating, A may refuse an expensive gift from $B$ because the gift would imply an intensity to the relationship that $\mathrm{A}$ does not feel. If $\mathrm{A}$ is a young adult, she may reject a gift of money from her parents because accepting the gift would compromise her efforts to become independent. In both cases, the affective cost of the gift to the donee swamps its monetary value. ${ }^{57}$

The totemic aspect of a gifted object is also one reason why donors often make gifts of objects rather than equivalent amounts of cash. Cash is a cold, market commodity, while objects are often invested with warmth. Furthermore, the gift of an object rather than of cash shows that the donor not only cares about the donee but has thought about the donee's special characteristics and has expended on the donee not simply money, which is a market element, but time and trouble, which are personal elements. Perhaps most importantly, an object, unlike cash, constitutes and persists as a totemic embodiment of the affective relationship between donor and donee. Therefore, although there are occasions when cash is an appropriate gift, there are many cases-such as a gift by a houseguest, or a gift to a loved one on Valentine's Day, or a gift to a spouse on a birthday or anniversary-where a gift of cash would be regarded as bizarre, deeply insulting, or both. (These factors also help explain why donors often give gift certificates rather than an equal amount of cash. Although a gift certificate may be an imperfect substitute for an object, it is sufficiently specific both to require and reflect some thought about the donee; its acquisition entails some time and effort by the donor; and it can be converted into a totemic object.)

The difference between gifts of cash and gifts of objects is unwittingly illustrated in an article by an economist, Joel Waldfogel, entitled The Deadweight Loss of Christmas. ${ }^{58}$ This article concluded that gifts of objects, rather than cash, are inefficient, because the donor usually chooses an object whose economic value to the donee is less than the donor's cash outlay for the object. Waldfogel's conclusion was based

57. Presumably for this reason, the Swiss Code of Obligations provides that a legal representative of a person who lacks capacity, such as a minor, may forbid the beneficiary from accepting a gift or require her to return a gift. See Code des obligation [Co.] art. 24l, translated in CoMmercial LAWS OF THE WORLd, SWITZERLAND 43 (1995).

58. Joel Waldfogel, The Deadweight Loss of Christmas, 83 AM. Econ. REv. 1328 (1993). 
on survey evidence. In one survey, donees were asked, "[a]part from any sentimental value of the [gifted] items, if you did not have them, how much would you be willing to pay to obtain them?"59 In the second survey, respondents were asked to estimate the value of gifts as the "amount of cash such that you are indifferent between the gift and the cash, not counting the sentimental value of the gift." Waldfogel's summary, "[t]he ... respondents to the second survey estimate that $\$ 509$ was paid for their gifts, but they value these gifts at only $\$ 462 . " 61$ Waldfogel concluded that there was an even larger deadweight loss in the first survey. ${ }^{62}$

In fact, however, Waldfogel naively misreported his own data. Waldfogel never asked the respondents how they valued the gifts. Instead, he asked only how they valued the gifts apart from sentimental value. Having instructed the respondents to eliminate sentimental value from their responses, Waldfogel then took it upon himself to eliminate sentimental value from value, thereby substituting his own utility calculus for those of his respondents. ${ }^{63}$

\section{IV}

\section{Donative Promises and the Nature of Gifts}

The difference between gifts and bargains, explored in Part III, strikingly illuminates the donative-promise principle. In the past, the

\footnotetext{
59. Id. at 1331 (emphasis added).

60. Id. (emphasis added).

61. Id. at 1332 (emphasis added).

62. Id. at 1331-32.

63. One of my students, Ed Anderson, makes another criticism of Waldfogel's methodology:

Waldfogel's article presents itself as being quite a bit more scientific than it actually is. In particular, he has not eliminated other potential ways to read his data. IValdfogel is measuring utility by comparing what students estimate the gift-giver paid (price) against what the students say they themselves would pay for the identical gift (value, survey I) and against the amount for which the students would sell the gift (value, survey 2). [In Waldfogel's view,] the average ratio of value/price in both surveys of less than one represents persistent inability of the gift-giver to efficiently fulfill the desires of the recipient (resulting in the overall deadweight loss of utility).... Notice, however, that the data is also consistent with a model of perfectly efficient utility matching, but persistently biased estimates of relative bargain-hunting abilities. On average, the students estimate that their givers paid higher prices than they themselves would have paid. Couldn't one conclude that the students consistently, but erroneously, see themselves as better shoppers than their henefactors? ... I suspect Waldfogel's data is at least partially skewed by this phenomenon, which he does not account for. If so, he is overestimating the deadweight loss by some unknown amount. He needs to use an objective measure of price in his denominator (he needs to get the gift-givers to bring in their receipts). As it is, Waldfogel has really measured perceived deadweight loss of Christmas, rather than actual deadweight loss of Christmas.
}

Ed Anderson, Discussion Questions for Seminar in Contracts Theory (Sept. 8, 1996) (unpublished paper, on file with author).

Notwithstanding his analysis, Waldfogel primarily gives gift certificates rather than cash. See Hubert B. Herring, Dislike Those Suspenders? Don't Complain, Quantify!, N.Y. TIMEs, Dec. 25, 1994, at C3. 
justifications for this principle have often been rested on process grounds. An examination of the nature of gifts, however, provides strong substantive reasons for not enforcing simple donative promises.

\section{A. The Moral Importance of Keeping Donative Promises Out of the World of Contract}

To begin with, the world of contract is a market world, largely driven by relatively impersonal considerations and focused on commodities and prices. The impersonal organs of the state are an appropriate means to enforce promises made in such a world. In contrast, much of the world of gift is driven by affective considerations like love, affection, friendship, gratitude, and comradeship. That world would be impoverished if it were to be collapsed into the world of contract.

An analogy can be drawn here to an individual's personal attributes. Margaret Radin has pointed out that individuals have a great number of personal attributes that potentially could be sold on markets"commodified." Some of these attributes, like the capacity for labor and creative ability, can legally be sold. Other attributes, like sexuality and body organs, can be given but cannot legally be sold. These attributes are alienable but not commodifiable. Although various explanations can be advanced for legal rules that make personal attributes alienable but not commodifiable, the best explanation is Radin's:

We are now in a better position to understand how conceiving of personal things as commodities does violence to personhood, and to explore the problem of knowing what things are personal ....

To conceive of something personal as fungible ... assumes that persons cannot freely give of themselves to others. At best they can bestow commodities. At worst ... the gift is conceived of as a bargain. Conceiving of gifts as bargains not only conceives of what is personal as fungible, it also endorses the picture of persons as profit-maximizers. A better view of personhood should conceive of gifts not as disguised sales, but rather as expressions of the interrelationships between the self and others. To relinquish something to someone else by gift is to give of yourself. Such a gift takes place within a personal relationship with the recipient, or else it creates one. Commodification stresses separateness both between ourselves and our things and between ourselves and other people. To postulate personal interrelationship and communion requires us to postulate people who can yield personal things to other people and not have them instantly become fungible. Seen this way, gifts diminish separateness. This is why (to take an obvious example) people

64. Margaret Jane Radin, Market-Inalienability, 100 HARv. L. REv. 1849 (1987). 
say that sex bought and paid for is not the same "thing" as sex freely shared. Commodified sex leaves the parties as separate individuals and perhaps reinforces their separateness; they only engage in it if each individual considers it worthwhile. Noncommodified sex ideally diminishes separateness; it is conceived of as a union because it is ideally a sharing of selves.

Not everything with which someone may subjectively identify herself should be treated legally or morally as personal.... The question whether something is personal has a normative aspect: whether identifying oneself with something-constituting oneself in connection with that thing-is justifiable. What makes identifying oneself with something justifiable, in turn, is an appropriate connection to our conception of human flourishing. ${ }^{65}$

Similarly, making simple, affective donative promises enforceable would have the effect of commodifying the gift relationship. Under an enforceability regime, it could never be clear to the promisee, or even to the promisor, whether a donative promise that was made in a spirit of love, friendship, affection, or the like, was also performed for those reasons, or instead was performed to discharge a legal obligation or avoid a lawsuit. Accordingly, gifts made pursuant to simple, affective donative promises would be seriously impoverished, because at the point of the transfer, the promisor's motives would invariably be mixed. As one of my students, Thomas Mayhew, remarked,

[w]e use gifts to indicate our favorites-if we choose to withdraw our affections, then we should not be forced into making the transfer nevertheless. The forced transfer is no longer an indication of our feelings-it is a redistribution without social meaning. The enforcement (against the will of the giver) of a gift removes all characteristics of its "gift-ness" except the transfer of ownership. If a gift loses its "gift-ness" when litigation occurs, then that seems to be a reason to minimize the presence of law in the gift-giving and -receiving process. ${ }^{66}$

In short, legal enforcement of simple, affective donative promises would move the commodity rather than the relationship to the forefront, would essentially convert the gift promise into a cash equivalent, and would submerge the affective relationship that the gift was intended to totemize. Simple donative promises would be degraded into bills of exchange, and the gifts made to keep such promises would be degraded into redemptions of the bills. To protect a few promisees, and perhaps a few promisors, an enforceability regime would cut off something very

65. Id. at 1907-08.

66. Thomas Mayhew, Discussion Questions for Seminar in Contracts Theory (unpublished paper, on file with author). 
important in social life, and harm donative promisors, and even donative promisees, as a class.

It can now be seen that the principle that simple donative promises are unenforceable does not show that the law fails to value donative promises. Just the opposite is true. The principle that simple donative promises are unenforceable is justified not because simple donative promises are less important than bargain promises, but because they are more important. The world of gift is a world of our better selves, in which affective values like love, friendship, affection, gratitude, and comradeship are the prime motivating forces. These values are too important to be enforced by law and would be undermined if the enforcement of simple, affective donative promises were to be mandated by the law. It is just because these values are usually missing from the more impoverished world of contract that the law must play a central role in that world.

\section{B. The Moral Obligation of a Donative Promisee}

An exploration of the world of gift reveals still another substantive reason for not enforcing simple donative promises. Those who would make simple donative promises enforceable usually focus on the moral obligations of the promisor. However, just as a donative promisor has moral obligations, so too does a donative promisee. Suppose that a promisor lacks an objectively satisfactory excuse for not keeping a promise, but nevertheless does not want to perform. Perhaps the promisor has an excuse that he believes is satisfactory, although reasonable persons would not agree. Perhaps the promisor has simply changed his mind. Under the morality of duty, the promisor is obliged to keep his promise. In the world of contract, if the promisor has a duty to keep his promise, it is normally proper for the promisee to enforce the promise. In the world of gift, however, matters are not so straightforward. It may be wrong for a donative promisor to break a donative promise but also wrong for the promisee to insist on performance, because under the morality of aspiration, where a donative promise is made for affective reasons the donative promisee is normally obliged to release a repenting promisor.

Andrew Kull's third-wave article, Reconsidering Gratuitous Promises ${ }^{67}$ is instructive in this regard. Kull, like most other third-wave commentators, argues that simple donative promises should be enforceable. ${ }^{68}$ However, Kull also concludes that if, say, Uncle has made a donative promise to Nephew and later changes his mind, it might well be

67. Kull, supra note 34 .

68. See id. at 59-64. 
"unthinkable" for Nephew to sue Uncle. ${ }^{69}$ But if suit is unthinkable, how can enforceability be desirable? The donative-promise principle prevents the unthinkable from occurring, by capturing, as an enforceability regime would not, the promisee's moral obligation to release a repenting promisor from a simple, affective donative promise. ${ }^{70}$

\section{Explaining the Exceptions to the Donative-Promise Principle}

The distinction between the world of gift and the world of contract explains not only the donative-promise principle, but its exceptions. For example, the distinction helps explain the role of appropriate formalities in making donative promises enforceable. Traditionally, the effect of such formalities has been explained on process grounds: the use of an appropriate form provides assurance against perjurious claims and helps ensure deliberation by the promisor. The distinction between the world of contract and the world of gift, however, suggests a substantive ground for the role of appropriate formalities: if a donative promisor casts his promise in a special form that is specifically and popularly associated with legal enforceability - as in the case of the seal at early common law-he declares by his use of the form that he is deliberately moving out of the affective world of gift and into the legal world of contract. This declaration justifies the law in putting aside concerns about the effect that enforceability would have on the world of gift. It also justifies putting aside concerns about allowing a promisor to repent, because by deliberately moving his promise into the world of contract, the promisor indicates that he wants his promise cut loose from such concerns.

The distinction between the world of contract and the world of gift also helps explain the modern rule that a promise to make compensation for a past benefit that gave rise to a moral obligation is enforceable. ${ }^{71}$ Such promises are typically made between strangers or business associates, rather than between persons in an affective relationship, and have the look and feel of repayment. This is most obviously true in the paradigm cases in this area-promises to pay a debt that is barred by the

69. See id. at 63 .

70. My colleague Stephen Sugarman points out that the moral obligation of a donative promisce may also be conceptualized in terms of generosity. Under the donative-promise prineiple, a donative promisor may repent without an objectively satisfactory excuse, even though the generous thing would be to keep the promise to avoid disappointment to the promisee. In contrast, under an enforceability regime, a donative promisee could insist on performance, even though the generous thing would be to release the repenting promisor. As between donative promisor and donative promisee, the better altemative is to allow a donor to be ungenerous rather than to give legal muscle to an ungenerous promisee.

The obligation of an affective promisee to release a repenting promisor can also be explained on the basis of implication. It may be an implied term of an affective donative promise that the promisee will exercise tolerance if the promisor changes his mind.

71. See discussion supra pp. 836-36. 
statute of limitations, by infancy, or by a discharge in bankruptcy-all of which involve commercial relationships. It is also true, however, even in cases where the relationship was not commercial in the normal sense. (For example, in the leading case of Webb v. McGowin, ${ }^{72}$ the promisee had incurred serious bodily injury by rescuing the promisor, who was apparently a fellow employee or a stranger rather than a personal friend, from serious injury or death.) Indeed, if the promisor and promisee were in an affective relationship at the time a benefit was conferred, the benefit is likely to have been conferred as a gift, which there would be no moral obligation to repay, so that the promise would not be enforceable even under the modern rule.

Of course, the promise in these cases is motivated by moral rather than self-seeking reasons. This is what makes it a donative promise. But the fact that past-benefit promises are essentially promises of repayment, and typically are not made for affective reasons, shows how distinct such promises are from simple donative promises. ${ }^{73}$

The distinction between the world of contract and the world of gift also helps explain why relied-upon donative promises are enforceable, and why they are enforceable only to the extent of the reliance. A donative promisor's refusal to reimburse the promisee for a diminution in the promisee's wealth resulting from reliance on the promise takes the relationship out of the affective realm. Requiring the promisor simply to make good such a diminution is not the same thing as requiring the promisor to keep the promise in full-bore fashion apart from such a diminution. Furthermore, even under the morality of aspiration, a donative promisee is not morally obliged to excuse a promisor from a duty that is based on, and limited to, the reimbursement of costs incurred in reliance on the promise. ${ }^{74}$

72. 168 So. 196 (Ala. Ct. App. 1935), cert. denied, 169 So. 199 (Ala. 1936).

73. Cf. Commissioner v. Duberstein, 363 U.S. 278 (1960). The issue in this case was whether certain transfers constituted taxable income or nontaxable gifts to the recipients. The Court, in a fourjustice plurality opinion, stated that not every transfer that is a gift for purposes of private law is also a gift for purposes of the Intemal Revenue Code. It elaborated:

The course of decision .... makes it plain that the statute does not use the term "gift" in the common-law sense [of a transfer without consideration or other compensation], but in a more colloquial sense. This Court has indicated that a voluntary executed transfer of his property by one to another, without any consideration or compensation therefor, though a common-law gift, is not necessarily a "gift" within the meaning of the statute.... [1]f the payment proceeds primarily from "the constraining force of any moral or legal duty," ... it is not a gift [for tax purposes].... A gift in the statutory sense... proceeds from a "detached and disinterested generosity,"... "out of affection, respect, admiration, charity or like impulses."

Id. at 285 (citations omitted).

74. I have focused, in Part IV, on the substantive criticism of the donative-promise principle in the third-wave commentary. Some of that commentary also criticizes the donative-promise principle on the ground that the process rationale for the principle is not well-founded. One of these criticisms is that the process rationale for the donative-promise principle is based on an incorrect psychological proposition-that people are generally untrustworthy, selfish, and grasping, so that the principle is 
Finally, the distinction between the world of contract and the world of gift also helps to show why a special rule may govern donative promises to charities: such promises are not made in the context of an affective relationship, and little if any affective significance would be lost by enforcing such promises.

The distinctions between the world of contract and the world of gift also provide support for the rule, sometimes suggested, ${ }^{75}$ that a simple donative promise should be enforceable against the promisor's estate if the promisor had not revoked and the promise is in writing. Such a rule would allow a donative promisor to freely repent and would apply only in suits involving parties who were not in an affective relationship.

\section{$\mathrm{V}$ \\ ANOTHER LOOK AT DOCTRINE}

One strand of the commentary in the third wave, examined in Parts III and IV, argues that simple donative promises should be enforceable on the basis of social propositions. Another strand argues that the donative-promise principle is not actually the law. Among the most important works in this strand is Yorio and Thel's article, The Promissory Basis of Section $90{ }^{76}$ Yorio and Thel's principal thesis is striking. As a matter of existing doctrine, they say, "If a promise"-any promise"is identified as serious... the court will enforce it." Accordingly,

needed to block widespread perjurious allegations that a donative promise has been made. See, e.g., Baron, supra note 51, at 172-75. This criticism is not very persuasive. The process rationale is not based on the proposition that people are generally untrustworthy, but on the proposition that the potential for untrustworthy behavior is sufficiently large that making simple donative promises enforceable would lead to trouble. To put this differently, the issue is not whether people are generally selfish or generally altruistic-some people are altruistic, some people are selfish, and most people are altruistic and selfish. The issue is how rules of law should reflect these psychological realities. Furthermore, the trustworthiness critique can be tumed on its head. Although an unenforceability regime is based in part on a concern that untrustworthy actors may opportunistically claim they are donative promisees, such a regime may also be rested on a regard for trustworthiness as a device that will normally ensure the performance of donative promises. In this light, an argument for enforceability on the ground that people are basically trustworthy seems somewhat inconsistent with an argument that donative promises need to be legally enforced.

Another criticism of the process rationale for the donative-promise principle is that donative promises are often deliberatively made. See, e.g., Kull, supra note 34, at 53-54. This criticism is also not persuasive. The issue is not whether donative promises are often deliberatively made, but whether a significant proportion of donative promises is likely not to have been deliberatively made. Experience and practical judgment suggests that a significant proportion of promises made for affective reasons are made impulsively. See, e.g., Dougherty v. Salt, 124 N.E. 94 (1919). Here, Aunt made a donative promise to Nephew on the spur of the moment after Aunt had said to Nephew's guardian that she was going to take care of the child and loved him very much, and the guardian taunted her by responding, "I know you do, Tillie, but your taking care of the child will probably be done like your brother and sister done, taking it out in talk." Id.

75. See, e.g., Fellows, Donative Promise Redux, supra note 34, at 36-37.

76. Yorio \& Thel, supra note 34; see also Thel \& Yorio, supra note 34.

77. Yorio \& Thel, supra note 34 , at 113. 
simple donative promises are enforceable under existing law even though informal and unrelied upon. I will call this the seriousness thesis.

By and large, Yorio and Thel attempt to establish the seriousness thesis only indirectly, by arguing two more limited, subsidiary claims. The first claim is that under contract law, expectation damages, not reliance damages, must be awarded in what Yorio and Thel call "Section 90 cases." I will call this the damages claim. The second claim is that courts do not require reliance in "Section 90 cases," but only the prospect of reliance. ${ }^{78}$ The prospect of reliance is said to be significant because it is a proxy for the seriousness of the promise: if reliance by the promisee was within the promisor's reasonable expectation, the promisor must have made the promise seriously, ${ }^{79}$ and under the seriousness thesis, if the promisor made the promise seriously, the promise will be enforced. I will call this the reliance claim.

Because Yorio \& Thel's article is so important and so well-argued, and because it is echoed by other commentary in the third wave, it deserves close and extensive attention. In the remainder of this Part, I will consider five aspects of the Yorio and Thel article: their methodology, the damages claim, the reliance claim, the seriousness thesis, and the normative subtext that underlies their enterprise.

\section{A. The Methodology}

Yorio and Thel are at pains to maintain that their enterprise is not normative, but positive or descriptive-that their concern is only what the law actually is, not what the law should be. "Our thesis is not that the basis of Section 90 ought to be promise. Rather, we describe and analyze the reported cases and show that the basis of the section is promise." ${ }^{\text {T0 }}$ They identify themselves here with Williston: "The key to Williston's position is found" in his statement on the floor of the A.L.I. in that "[t]he endeavor in this Restatement is to restate the law as it is, not as new law." 81

A purely descriptive legal enterprise must begin with a definition of the population of authorities that is to be described. Yorio and Thel never leap this hurdle, because they never make clear what constitutes a "Section 90 case." The term, as they use it, cannot mean cases decided under section 90 , because many of the cases they cite were decided before the publication of Restatement (First). The term cannot mean donative-promise cases, because most of the cases they cite involve commercial promises, and in any event, many donative-promise cases

78. See id. at 152-60.

79. See id. at 126-27.

80. Id. at 114-15 (emphasis in original).

81. Id. at 122 . 
involve neither reliance in general nor section 90 in particular. The term cannot mean cases based on the promisee's actual reliance, because one of Yorio and Thel's claims is that the promisee's actual reliance is irrelevant.

I will return below to the severe problems of coherence and underinclusiveness in the kind of population of authorities that Yorio \& Thel utilize. ${ }^{82}$ Assume for the moment, however, that the relevant population can be coherently defined in some way so that it consists of the kind of authorities that Yorio and Thel consider. This brings us to an even deeper problem with their methodology. An unspoken but underlying premise of Yorio and Thel's enterprise is that it is possible to interpret doctrinal authority wholly without regard to what the law should be as a matter of morals, policy, and experience. This premise is incorrect, and Yorio and Thel's entire enterprise is correspondingly flawed.

In reasoning from precedent, a deciding court can focus either on what a precedent court said or on what it did. Focusing just on what a precedent court did will almost never yield a meaningful rule, because the rule of the precedent would only be that on all the facts of the precedent the result reached in the precedent should follow. Because no two cases are alike, as a practical matter such a "rule" would be meaningless. Normally, therefore, reasoning from precedent begins with what a precedent court said, rather than what it did.

Nevertheless, a deciding court always has power to distinguish away what a precedent court said in favor of what it did, on the ground that what the court did was narrower, broader, or just different than what it said. The extent to which courts exercise this power, and more generally the way in which courts interpret a precedent, always depends in part on the extent to which the rule announced in the precedent is congruent or incongruent with the rule that the deciding court would adopt on a clean slate based on those propositions of morality, policy, and experience that the courts can properly take into account. ${ }^{83}$ Just such a principle has guided the Restatements in modern times: Restatement rules are to "give weight to all of the considerations that the courts, under a proper view of the judicial function, deem it right to weigh" in their deliberations. ${ }^{84}$

Accordingly, notwithstanding Williston's disingenuous statement that "[t]he endeavor... is to restate the law as it is," ${ }^{85}$ Section 90 , like many other Restatement provisions, is famous not because it stated "the law as it is," but because it was a radically transformative statement of

82. See infra Part V.B-D.

83. See EISENBERG, supra note 15, at 160-61.

84. Herbert Wechsler, The Course of the Restatements, 55 A.B.A. J. 147, 150 (1969).

85. Yorio \& Thel, supra note 34 , at 122. 
contract law. The basic paradigm under classical contract law was that donative promises were unenforceable as a class, except for anomalies, like promises under seal, that were explained away largely on historical grounds. Acting under this paradigm, for a long period of time many courts would not enforce even relied-upon donative promises, as such, ${ }^{86}$ although they gave relief when the underlying transaction could be artificially construed as a bargain ${ }^{87}$ or fell into one of several special categories-most prominently agency, bailments, charitable subscriptions, promises in contemplation of marriage, and promises to give land. ${ }^{88}$ In short, enforcement of relied-upon donative promises under classical contract law was categorical rather than principled-that is, enforcement was based on whether the promise fell within a designated subject-matter category, rather than on whether the promise should be enforced under the principle of reliance. In effect, these categories were unexplained anomalous exceptions to the basic paradigm that donative promises were unenforceable.

The accomplishment of section 90 was to transform the old paradigm, and its anomalous exceptions, by adopting a new principle-that donative promises are enforceable if relied upon. In fashioning the new principle, Williston was able to summon up, as authority, the cases that constituted anomalies under the old paradigm. If, however, a reliance principle was not socially justified, Williston should and undoubtedly would have concluded that the previously anomalous cases should be rejected or cabined off, not used as raw material for a transformation. To think that Williston was only stating the law "as it is" is therefore to mistake the fundamental social choice that Williston made.

\section{B. The Damages Claim}

The defect in Yorio and Thel's methodology, of trying to state what the relevant law is without regard to what it should be, is well illustrated by the way in which Yorio and Thel try to establish their damages claim, that the law requires damages in "Section 90 cases" to -be measured by the promisee's expectation. As Yorio and Thel recognize, Restatement (Second) allows reliance damages under section 90. Furthermore, many courts have awarded reliance damages in reliance-based cases.

A recent example is First National Bank v. Logan Mfg. Co, ${ }^{89}$ which, like many of Yorio and Thel's cases, is commercial rather than

86. See, e.g., cases cited in note 37 , supra.

87. See, e.g., Siegel v. Spear \& Co., 138 N.E. 414 (N.Y. 1923).

88. See Boyer, Principle from Precedents $I$, supra note 24; Boyer, Principle from Precedents II, supra note 24.

89. 577 N.E.2d 949 (Ind. 1991). This case was decided around the time that The Promissory Basis of Section 90 was published, and may have been unavailable to Yorio and Thel when their 
donative. Garrett and Moore sought to borrow funds from First National Bank to purchase a plastics business and move it to Indiana. Brandt, a representative of the Bank, orally assured Garrett and Moore that the necessary loan would be made, and prepared a written loan application for them to sign. The application was approved by the Bank, subject to the condition that the loan was guaranteed by the state of Indiana. In the end, however, the Bank did not grant the loan, and Garrett and Moore sued. The court concluded that the Bank had not breached an oral contract, because when Brandt gave his oral assurance the Bank had not yet agreed on the terms of the loan, and had not breached a written contract, because a condition to that contract-the guarantee by Indiana-had not been fulfilled. However, the court held, Garrett and Moore were entitled to relief on a theory of promissory estoppel, because they had relied to their detriment upon Brandt's assurances that the bank would lend the money.

The court then turned to the issue of remedy, and self-consciously adopted a reliance measure:

Having concluded that the appropriate theory of recovery is promissory estoppel, we look again to the Restatement for guidance on the measure of damages. Section 90 provides that "[t]he remedy granted for breach may be limited as justice requires."...

We conclude that under the circumstances here, damages such as are required to prevent injustice are those referred to as "reliance damages." ...W We conclude that justice does not require the award of lost profits, ...",90

In the face of authorities like Restatement (Second) and First National Bank, Yorio and Thel's basic strategy is to stress those authorities in their populatiou that support expectation damages, and to explain away those authorities that do not. Yorio and Thel forcefully marshall the authorities in their population to make their point. The problem is that the same kind of population can be marshalled with equal force to make the opposite point by stressing authorities, like Restatement Second and First National Bank, that support reliance damages, and explaining away those that do not. For example, all or almost all of the cases that Yorio and Thel rely upon for their assertion that the law requires expectation damages to be awarded in "Section 90 " cases can be explained away on one or more of the following grounds:

article was written. However, there are other, earlier cases just like it. See, e.g., Westside Galvanizing Services, Inc. v. Georgia-Pacific Corp., 921 F.2d 735, 739 (8th Cir. 1990).

90. First National Bank, 577 N.E.2d at 956. 
(1) The case involved a commercial promise, not a donative promise. ${ }^{91}$ Most commercial promises are either part of an express or implied bargain or in aid of a bargain, and therefore should be enforceable by expectation damages for much the same reasons that support expectation damages for explicit bargains.

(2) The case involved a noncommercial bargain like, "If you take care of me I will leave you $\$ 20,000$ in my will." ${ }^{12}$

(3) The measure of damages was not at issue. ${ }^{93}$

(4) On the facts of the case, reliance damages were identical to expectation damages, so that the damage award can be characterized in either way. ${ }^{94}$

(5) The promisee's reliance was not readily quantifiable, ${ }^{95}$ so that expectation damages either had to be, or reasonably could be, used as a surrogate for reliance damages, just as reliance damages are used as a surrogate for expectation damages when expectation damages are not readily quantifiable. ${ }^{96}$

(6) The case arose before the late $1940 \mathrm{~s} .{ }^{97}$ All cases arising before that time are of limited persuasiveness on the issue of remedy, because until the explicit acceptance of reliance damages beginning around the 1950 s, the courts may have assumed, like Williston, that the only ineasure open to them in a contracts case was the expectation measure.

(7) The case imvolved a charitable subscription, a type of donative promise that has traditionally been given special treatment. ${ }^{98}$

In short, even assuming that the population of authorities Yorio and Thel assembled is coherent, Yorio and Thel do not establish their claim concerning damages as a descriptive matter. Given a population like that used by Yorio and Thel, as a descriptive matter it is equally plausible to stress the authorities that support the award of expectation damages and explain away those that do not, or to stress the authorities that support the award of reliance damages and explam away those that do not. "I s" therefore depends on "ought."

91. See, e.g., Janke Const. Co. v. Vulcan Materials Co., 527 F.2d 772 (7th Cir. 1976); Graddon v. Knight, 292 P.2d 632 (Cal. 1956).

92. See, e.g., DeCicco v. Schweizer, 117 N.E. 807 (1917); Hamer v. Sidway, 27 N.E. 256 (N.Y. 1891).

93. See, e.g., Ricketts v. Scothom, 77 N.W. 365 (Neb. 1898).

94. See, e.g., Devecmon v. Shaw, 14 A. 464 (Md. 1888).

95. See, e.g., Feinberg v. Pfeiffer Co., 322 S.W. 2d 163 (Mo. App. 1959).

96. See, e.g., Security Stove \& Mfg. Co. v. American Ry. Express Co., 51 S.W.2d 572 (Mo. C. App. 1932).

97. See, e.g., Ricketts v. Scothorn, 77 N.W. 365 (Neb. 1898).

98. See, e.g., Salsbury v. Northwestern Bell Tel. Co., 221 N.W.2d 609 (Iowa 1974). 


\section{The Reliance Claim}

In much and perhaps all of their discussion, Yorio and Thel conflate bargain promises with donative promises. Since Yorio and Thel's claims are universal, however, the claims can be disaggregated and restated to apply to bargain promises and donative promises separately. Because I am concerned here only with donative promises, and because the most significant impact of Yorio and Thel's article concerns donative promises, in the balance of this Article I will treat their claims in this disaggregated way.

Although Yorio and Thel's presentation in The Promissory Basis of Section 90 stresses their damages claim, the reliance claim-that a donative promise is enforceable even if the promisee has not actually relied, so long as there was a prospect of reliance-is more crucial for their argnment. To begin with, if the reliance claim is wrong, and actual reliance is required to make a simple donative promise enforceable, then the damages claim, that expectation damages are required if a donative promise is enforceable at all, would be left dangling.

For example, suppose that Aunt promises Nephew $\$ 4,000$ to allow Nephew to buy forty $\$ 100$ opera tickets over the course of the opera season. Assume, for this hypothetical, that the rule is that actual reliance is required to make a donative promise enforceable at all, but once the promise is enforceable at all, expectation damages are required. Applying this rule to the hypothetical, the result would be that if Nephew purchases no tickets before Aunt revokes, he gets no damages, but if Nephew purchases just one $\$ 100$ ticket before Aunt revokes, he gets $\$ 4,000$ in damages. Such a result would be anomalous, and such a rule could induce opportunistic reliance, because a donative promisee might quickly rely a little bit just to make the promise enforceable. ${ }^{99}$ To avoid these difficulties, and at the same time establish the claim that expectation damages are required if a donative promise is enforceable at all, Yorio and Thel must show that whether a donative promise is enforceable at all is unrelated to whether the promisee has actually relied.

An even more important problem for Yorio and Thel is that, unless they can establish the reliance claim, they are out of court on the seriousness thesis, that the law enforces all seriously made promises. A promise that is seriously made may be broken before it has been relied upon. Therefore, if actual reliance (or some other independent element, like a past benefit conferred) is required to make a donative promise enforceable, the thesis that seriousness is enough would fail.

Yorio and Thel's damages claim is forcefully, if unconvincingly, argued. In contrast, the reliance claim does not even rise to the level of

99. In contrast, under a reliance-damages regime, the promisee is only reimbursed for her costs, so that the promisee's reliance ordinarily will not result in a net benefit to her. 
plausibility. To begin with, section 90 in both Restatements explicitly requires reliance. Restatement (First) section 90 provides:

A promise which the promisor should reasonably expect to induce action or forbearance of a definite and substantial character on the part of the promisee and which does induce such action or forbearance is binding if injustice can be avoided only by enforcement of the promise. ${ }^{100}$

Similarly, Restatement (Second) section 90(1) provides:

A promise which the promisor should reasonably expect to induce action or forbearance on the part of the promisee or a third person and which does induce such action or forbearance is binding if injustice can be avoided only by enforcement of the promise. ${ }^{101}$

In addition to the Restatements, the case law explicitly requires reliance for the enforceability of donative promises, other than those that are enforceable on the basis of some other special principle, such as promises to compensate for a past benefit that gave rise to a moral obligation. ${ }^{102}$

100. Restatement (First) of Contracts $\$ 90$ (1932) (emphasis added).

101. Restatement (SECOND) OF Contracts $\$ 90(1)$ (1981) (emphasis added).

102. See, e.g., Feinberg v. Pfeiffer Co., 322 S.W.2d 163, 168 (Mo. App. 1959) ("Was there ... an act on the part of plaintiff, in reliance upon the promise contained in the resolution, as will... create an enforceable contract under the doctrine of promissory estoppel?"); Pitts v. McGraw-Edison Co., 329 F.2d 412, 416 (6th Cir. 1964) ("Although there may be other facts in the present case which prevent it from coming within the scope of [section 90], we believe that an important fact is that the plaintiff in no way altered his position for the worse by reason of defendant's letters of July 1 and July 20, 1955"); Hayes v. Plantations Steel Co., 438 A.2d 1091, 1096 (R.I. 1982) ("'T]he important distinction between Feinberg and the case before us is that in Feinberg the employer's decision definitely shaped the thinking of the plaintiff. In this case the promise did not."); Alden v. Presley, 637 S.W.2d 862 (Tenn. 1982); Bush v. Bush, 278 Ala. 244, 177 So. 2d 568 (1965) ("On the other hand, if Mama Bush... made the will but John and William did not act in reliance on the will ... then the promise would not be binding."); Dewien v. Estate of Dewien, 174 N.E.2d 875 (11l. App. 1961) ("The testimony in this case fails to support the claim that plaintiff 'acted in reliance upon the doctor's promise to her."').

In the face of overwhelming authority, Yorio and Thel nevertheless argue that their reliance claim is supported by case law. Pride of place in this part of their argument is given to the well-known. case, Devecmon v. Shaw, 14 A. 464 (Md. 1888). Here, Uncle promised Nephew that if Nephew went to Europe, Uncle would reimburse Nephew for his expenses. Nephew did go to Europe, but Uncle died before reimbursing him. The court held that Nephew was entitled to recover from Uncle's estate. Id. at 465.

Devecmon is a strange case for Yorio and Thel to rely upon in claiming that courts do not require reliance in section 90 cases. First, the case was decided fifty years before section 90 was published. Second, Nephew did rely on Uncle's promise, and the court based its judgment on that reliance:

[T] he testimony would have tended to show that the plaintiff incurred expense at the instance and request of the deceased, and upon an express promise by him that he would repay the money spent.... Great injury might be done by inducing persons to make expenditures beyond their means, on express promise of repayment, if the law were otherwise.... It is nothing to the purpose that the plaintiff was benefited [sic] by the 
In the face of Restatement (First) section 90, Restatement (Second) section 90(1), and the case law, and in the absence of a normative argument (which their methodology does not permit), Yorio and Thel's principal argument for the reliance claim is based on Restatement (Second) section 90(2), which provides that a charitable subscription or a marriage settlement is binding without proof that the promise induced action or forbearance. A marriage settlement, however, is unenforceable unless there has been a marriage. As to marriage settlements, therefore, section 90(2) is easily explained on the ground that when two persons marry after a marriage settlement has been made, they should be deemed to have relied upon the settlement, because once a person has been promised that he will be compensated if he takes a given act it will be literally impossible for either the person or a court to sort out whether and to what extent the act was motivated by the promise of compensation. Cardozo gave the quintessential expression to this thought in DeCicco v. Schweizer, ${ }^{103}$ itself a marriage-settlement case:

It will not do to divert the minds of others from a given line of conduct, and then to urge that because of the diversion the opportunity has gone by to say how their minds would otherwise have acted. If the tendency of the promise is to induce them to persevere, reliance and detriment may be inferred from the mere fact of performance. The springs of conduct are subtle and varied. One who meddles with them must not insist upon too nice a measure of proof that the spring which he released was effective to the exclusion of all others. ${ }^{104}$

\footnotetext{
expenditure of his own money. He was induced by this promise to spend it in this way, Id. instead of some other mode.
}

103. 117 N.E. 807 (N.Y. 1917).

104. Id. at 810. Similarly, in Klockner v. Green, 254 A.2d 782 (N.J. 1969), Edyth Klockner had promised Richard and Frances Klockner, her stepson and step-granddaughter, that if they would continue to look after her and visit her as they had been doing, she would leave them her property. Thereafter, Richard and Frances continued to look after and visit Edyth until she died. At that point, they learned that Edyth had never changed an existing will that left her property to others, apparently because she was superstitious about making a new will. Richard and Frances then brought suit against Edyth's executors and those who would take title under the will. At the trial, both Richard and Frances testified that they would have continued to look after and visit Edyth even if she had not made promises to compensate them. The court nevertheless held for Richard and Frances, referring to, among other sources, a discussion by Corbin "recognizing the complexity of motivating causes in human action." Id. at 783-84.

In Simmons v. United States, 308 F.2d 160 (4th Cir. 1962), a brewery offered a $\$ 25,000$ prize for catching a fish that the brewery had tagged and thrown back into the Chesapeake Bay. The chances of any one fisherman catching the fish were "miniscule." Id. at 162. Simmons, who knew of the offer, went fishing, but not for the express purpose of catching the prize-winning fish. The court held that the brewery was legally obliged to award the prize to Simmons, even though he did not go fishing for the express purpose of participating in the contest. "So long as the outstanding offer was known to him, a person may accept an offer for a unilateral contract by rendering performance, even if he does so primarily for reasons unrelated to the offer." Id. at 165 (footnote omitted). 
As to charitable subscriptions, Restatement (Second) section 90(2) seems to go beyond the case law, which for the most part requires either a bargain or reliance to make a charitable subscription enforceable. ${ }^{105}$ (Perhaps this is why in pressing the reliance claim Yorio and Thel heavily rely on Restatement (Second) section 90, which they reject in pressing the damages claim.) Moreover, section 90(2) can be and has been interpreted not to eliminate the requirement of reliance, but only to place on the promisee the burden of proving that the charity did rely in fact. ${ }^{105}$

Furthermore, to the extent that section 90(2) does support dispensing with reliance in the case of charitable pledges, that position can be justified on the grounds that the relationship between the promisor and the promisee is not affective, and that there is an important social policy in favor of charitable giving in a society, like ours, that stresses the promotion of general welfare through decentralized private institutions. ${ }^{107}$ Indeed, the modern cases that have enforced charitable subscriptions in the absence of reliance have tended to be based on this public-policy ground. Accordingly, the special treatment of charitable subscriptions in section $90(2)$ shows not that all donative promises are enforceable without reliance, but only that certain classes of donative promises should be enforceable without reliance-a proposition that is further established by Restatement (Second) section 86, concerning the enforcement of promises to make compensation for past benefits.

Moreover, Restatement (Second) section 90(2) actually undermines, rather than supports, Yorio and Thel's claim that actual reliance is not required in section 90 cases. If promises were enforceable under

105. See, e.g., Danby v. Osteopathic Hosp. Ass'n, 104 A.2d 903 (Del. 1954) (finding reliance in the form of commencement of construction of a hospital); Mount Sinai Hosp. v. Jordan, 290 So.2d 484 (Fla. 1974) (refusing to enforce a charitable subscription where there was no evidence of reliance); Congregation Kadimah Toras-Moshe v. DeLeo, 540 N.E.2d 691 (Mass. 1989) (same); DePauw Univ. v. Ankeny, 166 P. 1148 (Wash. 1917) (enforcing a charitable subscription where reliance consisted of using the subscription to induce other pledges and to gain state funding); 1. \& 1. Holdiug Corp. v. Gainsburg, 12 N.E.2d 532 (N.Y. 1938) (finding potential enforceability where the charity relied in seeking additional pledges and in incurring liabilities); Maryland Nat'l Bank v. United Jewish Appeal Fed., 407 A.2d 1130 (Md. 1979) (refusing to enforce a subscription in the absence of any evidence of reliance); In re Estatc of Timko v. Oral Roberts Evangelistic Ass'n, 215 N.W.2d 750 (Mich. Ct. App. 1974) (holding promise to make contributions for payments on a building enforceable where the building was purchased at the promisor's suggestion).

106. See, e.g., Congregation Kadimah Toras-Moshe v. DeLeo, 540 N.E.2d 691 (Mass. 1989).

107. See, e.g., Salsbury v. Northwestern Bell Tel. Co., 221 N.W.2d 609, 613 (lowa 1974); More Game Birds in America, Inc. v. Boettger, 14 A. 2d 778, 780 (N.J. 1940); Jewish Fed'n v. Barondess, 560 A.2d 1353 (N.J. Super. Ct. Law. Div. 1989); Congregation B'Nai Sholom v. Martin, 173 N.W.2d 504 (Mich. 1969). Assuming that charitable subscriptions are enforceable on the basis of public policy, rather than on the basis of actual reliance, then based on the principle that the measure of damages for breach of a given kind of promise should be based on the reason that the promise is enforceable, such promises should be enforceable to their full extent, rather than simply to the extent of any reliance. 
Restatement (Second) section 90 even without actual reliance, there would have been no need for section 90(2). By purporting to drop a reliance requirement for two special classes of donative promises, section 90(2) underscores that except in those cases, section 90 requires actual reliance.

Finally, Yorio and Thel's argument that the prospect of reliance screens out serious from nonserious promises is inconsistent with the nature of promising. A promise is a commitment. ${ }^{108}$ One who makes a commitment ordinarily must expect the commitment to be relied upon. ${ }^{109}$ Accordingly, all promises, not just some promises, ordinarily involve the prospect of reliance. The prospect of reliance may screen out those expressions that are promises from those that are not, but it does not screen out seriously made promises from other promises.

\section{The Seriousness Thesis}

Yorio and Thel advance the claims concerning damages and reliance in section 90 cases not only for their own significance, but as indirect support for the principal thesis that, as a descriptive matter, the law enforces all seriously made promises. However, if that thesis is examined directly, rather than indirectly, it is clear that it flies in the face of authority, on which it purports to rest.

To begin with, the seriousness thesis contradicts cases like Dougherty v. Salt, Fischer v. Union Trust, and Schnell v. Nell, in which the courts refused to enforce a donative promise although there could be no possible doubt that a promise was seriously made. ${ }^{.10}$

Next, the thesis contradicts the widespread legislative abolition of the enforceability of sealed promises: Such promises are normally seriously made, because they must be in writing, and putting a promise in writing is usually a serious act. The best explanation for these statutes, therefore, is that in the view of the legislatures, seriousness does not suffice to make a promise enforceable.

108. See Restatement (SeCond) of Contracts \& 2(1) (1981).

109. See, 1A. CoRBIN ON Contracts $\S 13$ (1963) (a promise is "an expression of intention that the [addressor] will conduct himself in a specified way or bring about a specified result in the future, communicated in such manner to [an addressee] that he may justly expect performance and may reasonably rely thereon.").

Joseph Raz has attempted a counterexample in which "Colin tells David: 'I promise to make you a gift of a million pounds on your 21 st birthday, but I beg of you: Until the time comes act as if I had not promised. It would ruin your character if you should start behaving in anticipation of your gift." Joseph Raz, Voluntary Obligations and Normative Powers, 46 ARISTOTELian Soc'y 79, 99 (Supp. Vol. 1972). The unrealistic character of this example underscores rather than negates that one who makes a promise expects it to be relied upon, and indeed Raz goes on to say that "We may well think that Colin was ill-advised to make the promise, because once made, David may have reasonable grounds for relying on it..." Id.

I10. See supra text accompanying notes 1-11. 
Finally, and most important, the seriousness thesis is in conflict with hundreds of cases that refuse to enforce seriously made commercial promises, such as the cases that refuse to enforce a promise, no matter how seriously made, to accept part payment in full discharge of a debt; ${ }^{\prime \prime \prime}$ the cases that refuse to enforce a promise, no matter how seriously made, to modify a contract nonreciprocally; ${ }^{12}$ the cases that refuse to enforce a promise, no matter how seriously made, to hold an offer open for a fixed period of time; ${ }^{113}$ and the cases that refuse to enforce a promise, no matter how seriously made, that is exchanged for an illusory counter-promise. ${ }^{114}$

The hundreds of cases holding that seriously made commercial promises are unenforceable may very well have been incorrectly decided. In fact, in my view most of them are incorrectly decided, because commercial promises either involve actual or implied bargains or are in aid of bargains and therefore should be enforceable like bargains. ${ }^{115}$ But propositions like Yorio and Thel's seriousness thesis, that take the form "solely on the basis of the authorities, the law is ...," cannot rest on arguments that hundreds of cases were wrongly decided. Similarly, although it can be convincingly argued that there is an emerging trend to enforce all commercial promises, ${ }^{116}$ the basis of such enforceability is not that such promises are serious, but that they are commercial. In any event, Yorio and Thel do not rely on this trend, and probably could not, because it is still only that - a trend. The identification of an emerging trend seldom depends solely on a simple counting process, but instead rests in part on a normative basis, because the identification of a trend is usually based on a preference for cases that go in a certain direction over those that do not.

Under the seriousness thesis, the doctrine of consideration would collapse into the issue whether a promise had been seriously made, and the principles of consideration would at most be rules of thumb to guide decision on that issue. That concept of consideration certainly could be defended normatively (although I would disagree with it insofar as it ignored the distinction between the world of contract and the world of

111. See, e.g., Foakes v. Beer, 9 App. Cas. 605 (H.L. 1884).

112. See, e.g., Gross v. Diehl Specialties, Int'1, Inc., 776 S.W.2d 879 (Mo. Ct. App. 1989); Vito v. Pokoik, 150 A.D.2d 331, 540 N.Y.S.2d 858 (1989); Okemah Construction, Inc., v. Barkley-Farmer, Inc., 583 S.W.2d 458 (Tex. Civ. App. 1979); Wessman, supra note 34 (discussing the modification rule and collecting recent cases).

113. See, e.g., Dickinson v. Dodds, 2 Ch. Div. 463 (Ct. App. Ch. Div. 1876); Wessman, supra note 34 (discussing the firm-offer rule and collecting recent cases).

114. See, e.g., Propane Industrial, Inc., v. General Motors Corp., 429 F. Supp 214 (W.D. Mo. 1977); Wickham \& Burton Coal Co. v. Farmers' Lumber Coal Co., 179 N.W. 417 (Iowa 1920).

115. See Melvin Aron Eisenberg, The Principles of Consideration, 67 CoRnelz L. Rev. 640, 652-56 (1982).

116. See Farber, supra note 35, at 904-05. 
gift), but it cannot be defended on the ground that it is descriptive. Under the traditional doctrine of consideration, and even under the modern law of consideration, many kinds of promises that are seriously made are not only presumptively but conclusively unenforceable. When the entire population of contracts cases is considered in evaluating the seriousness thesis, the thesis cannot be even plausibly sustained. ${ }^{117}$

\section{E. The Normative Subtext}

Despite the failure of all of Yorio and Thel's claims, their work is extremely important. Ironically, however, the importance of their work is not descriptive, but normative. Notwithstanding their protestations, Yorio and Thel's work is clearly driven by a very strong normative preference for a deontological, promisor-based conception of contract law that focuses on promise-keeping as a desirable end in itself. Indeed, this implicit normative preference provides a much sounder base for their claims than does the positive-law methodology to which they explicitly appeal.

Yorio and Thel's aversion to reliance damages is a reflection of this preference, because they believe that affording a substantive and remedial role to reliance in contract law threatens the promisor-based conception of contract law. They premise, as did Williston, that a promise cannot be deemed enforceable if it is not enforceable to its full extent. "Judges actually enforce promises rather than protect reliance in Section 90 cases," 118 they say, as if measuring damages by reliance was not to "enforce promises." In their view, therefore, granting reliance damages reduces the population of enforceable promises.

Similarly, Yorio and Thel premise-here parting company with Williston-that if reliance is required to enforce a promise, then to that extent contract law is "reliance-based" rather than "promise-based." This premise apparently explains the title of their article-The Promissory Basis of Section 90. So, for example, they say that "reliance theory does not explain why in Section 90 cases courts insist that there be a promise. If the basis of recovery were harm caused by the defendant's conduct, it should not matter whether the conduct constituted a

117. A later article on past consideration, Thel \& Yorio, supra note 34, seems to back away from the seriousness thesis. This article advances the proposition that "the promise is what matters [in past consideration cases] and...the underlying moral obligation is important only as a screen for identifying important promises to enforce." $1 d$. at 1085. In addition, it argues that "[w]hen courts examine the moral obligation underlying a promise, they ask whether it is sufficiently compelling to justify intervention." Id. at 1100. But whether a promise is "important. . to enforce" and whether an underlying moral obligation is "sufficiently compelling" to justify enforcement of a following promise are different issues than whether a promise is seriously made.

118. Yorio \& Thel, supra note 34, at 111 (emphasis added). 
promise." 119 Here again, Yorio and Thel view the reliance principle as a threat to the promisor-based conception of contract law.

Yorio and Thel are right in viewing the reliance principle as a threat to a promisor-based conception of contract law, but they are wrong in thinking that the reliance principle is inconsistent with a promise-based conception of contract law. Yorio and Thel's premise that a promise cannot be deemed enforceable unless it is enforceable to its full extent is incorrect. Whether a court enforces a promise to its full extent is a different issue than whether a court enforces a promise. For example, courts often invoke the principle of Hadley $v$. Baxendale ${ }^{120}$ to cut off damages that are proximately caused by a breach. In such cases, the courts fail to enforce promises to their full extent, but we do not say that those courts have not enforced the promise. ${ }^{121}$ If liability is imposed when there would be no liability in the absence of the promise, then a promise has been enforced, regardless of the precise contours of the liability.

Yorio and Thel's premise that if reliance is required to enforce a promise, contract law is reliance-based, not promise-based, is also incorrect. It is impossible for any body of law to be simply "reliancebased." A plaintiff cannot bring an action in reliance, as such: she must say what she relied on. If what she relied on was a promise, then the body of law that she invokes is promise-based.

Indeed, in the end, even Yorio and Thel's seriousness thesis seems to be utilitarian and promisee-based, rather than deontological and promisor-based. Presumably, liability under Yorio and Thel's seriousness thesis would not turn on whether an addressor actually intended to make a promise and was actually serious, but on whether the addressee actually and reasonably believed the addressor made a promise and was serious. Accordingly, the application of Yorio and Thel's thesis does not, in the end, depend on whether a serious promise has actually been inade.

\section{CONCLUSION}

The law has a role to play in sectors of the donative-promise area. For example, the law has a role to play in restoring a diminution in the promisee's wealth caused by his reasonable reliance, and in enforcing, by appropriate damage measures, certain classes of donative promises that are not based on affective considerations. The law might also provide a facility for use by persons who have a specific intent to make a

119. Id. at 161-62.

120. 156 Eng. Rep. 145 (Ex. Ch. 1854).

121. See Melvin Aron Eisenberg, The Principle of Hadley v. Baxendale, 80 CALlF. L. Rev. 563 (1992). 
donative promise legally enforceable, provided the facility is designed so that it can be employed only by persons who use it deliberatively and understand its import. However, the relocation of simple, affective donative promises into the world of contract would entail costs, in the form of the impoverishment of the world of gift, that would greatly exceed any benefits. Furthermore, a rule that made simple, affective donative promises enforceable would fail to give proper recognition to the moral obligation of an affective donative promisee to release a repenting promisor. The morality of promise-keeping is a critical element in contract law, but it is only one part of a larger story.

What is said in this Article about the worlds of contract and gift can be transferred to a larger stage. Norms that are not legally enforceable are not for that reason of lesser importance, and are often of greater importance, than norms that are legally enforceable. Affective elements, like love and friendship, play a critical role in most of our lives, but norms associated with these elements are often not inappropriate for legal enforceability except at the margins. 